\title{
FROM AMERICA TO THE WORLD: PROTESTANT CHRISTIANITY'S CREATION OF RELIGIOUS LIBERTY
}

\author{
Dr. Peter A. Lillback \\ Presiden E Professor Westminster Theological Seminary, USA
}

\begin{abstract}
ABSTRAK: Setengah penduduk dunia hingga saat ini masih belum menikmati kebebasan beragama. Penganiayaan karena agama masih kerap terjadi di banyak tempat di dunia ini. Pada sisi lain, hasil-hasil penelitian melaporkan bahwa ada pengaruh langsung antara kebebasan beragama dan kemakmuran ekonomi. "Kemakmuran adalah hasil dari kebebasan, karena itu cara terbaik untuk meningkatkan kesejahteraan ekonomi suatu bangsa adalah dengan memastikan kebebasan bagi warganya." Tulisan ini pertama-tama akan menguraikan mengenai modelmodel hubungan gereja dan negara, dan kemudian menjelaskan dasar Alkitab mengenai kebebasan beragama. Selanjutnya tulisan ini menjelaskan mengapa pembelengguan kebebasan beragama atau hati nurani oleh negara adalah salah, meski dengan alasan untuk melindungi warga dari agama yang salah, atau bidat. Tulisan ini juga akan menelusuri penganiayaan karena agama dari jaman gereja mula-mula sampai pada kelahiran aliran Protestan, dan kemudian memaparkan mengenai perjuangan dan perlindungan kebebasan beragama. Selanjutnya tulisan ini memaparkan apa yang mendasari perlindungan kebebasan beragama dalam konstitusi Amerika, dan kemudian menelusuri perjuangan dan
\end{abstract}


perlindungan kebebasan beragama itu sebagai perjuangan seluruh dunia.

KATA KUNCI: kebebasan beragama, konflik agama, bidat, gereja mula-mula, protestanisme, kebebasan beragama di Amerika Serikat.

ABSTRACT: Half the population of the world to this day still has not experienced religious freedom. Religious persecution often still occurs at many places in the world. Research studies show that there is a direct correlation between religious freedom and economic prosperity. "Prosperity is the result of freedom, therefore the best way to improve the economic prosperity of a nation is to ensure freedom for its citizens." This article will first elaborate models of the relationship between church and state, and then explain the basic principle of the Bible regarding religious freedom. It further explains why incarceration of religious freedom or of conscience by the state is wrong, despite the reasons of protecting its citizens from false religion or from a cult. This paper will also explore religious persecution from the time of early church until the birth of Protestantism, and then speaks about the struggle and the protection of religious freedom. Furthermore this article goes into what underlies the constitutional protection of religious freedom in America, and then browse through the struggle and the protection of religious freedom as a struggle of the world.

KEYWORDS: religious freedom, religious conflict, heresy, early church, Protestantism, religious freedom in the United States of 
America.

Observers of America have long noted the American quest for liberty as well as the apparent connection between liberty and faith in the history of the United States. ${ }^{1}$ In 1835, for example, Tocqueville's Democracy in America was published, in which the well-known French political analyst commented that Americans believed religion "indispensable to the maintenance of republican institutions." 2 In 1922 G. K. Chesterton (18741936), called the United States "a nation with the soul of a church." 3 In this study, we review the arduous Protestant pursuit of religious freedom as it matured in the American context to become a universal human right. ${ }^{4}$

Religious liberty has foundational significance for western civilization. ${ }^{5}$ The United States in particular has affirmed that personal liberty is incomplete without religious liberty. ${ }^{6}$ An exemplar is American President Franklin D. Roosevelt's "Four Freedoms" address. On January 6, 1941 he outlined his hopes for world freedom:

In the future days which we seek to make secure, we look forward to a world founded upon four essential human freedoms.

The first is freedom of speech and expression-everywhere in the world. The second is freedom of every person to worship God in his own way-everywhere in the world. The third is freedom from want-which, translated into world terms, means economic undertakings which will secure to every nation a 
healthy peacetime life for its inhabitants-everywhere in the world. The fourth is freedom from fear-which, translated into world terms, means a worldwide reduction of armaments to such a point and in such a thorough fashion that no nation will be in a position to commit an act of physical aggression against any neighbor-anywhere in the world. . . Freedom means the supremacy of human rights everywhere. ${ }^{7}$

Sixty years later, American President George W. Bush declared on May 7, 2001,

It is not an accident that freedom of religion is one of the central freedoms in our Bill of Rights. It is the first freedom of the human soul: the right to speak the words that God places in our mouths. We must stand for that freedom in our country. We must speak for that freedom in the world. ${ }^{8}$

Yet religious liberty is recognized more broadly than just in the West, as it is a founding commitment of the United Nations. The Universal Declaration of Human Rights, adopted on December 10, 1948 proclaims:

Everyone has the right to freedom of thought, conscience and religion; this right includes freedom to change his religion or belief, and freedom, either alone or in community with others and in public or private, to manifest his religion or belief in teaching, practice, worship and observance. ${ }^{9}$ 
Religious liberty's global character is reinforced by the fact that it became a tenet of the Roman Catholic faith at the Second Vatican Council. Pope John Paul II, for example, said in his Message for the World Day of Peace, January 1, 1988, "Every violation of religious freedom, whether open or hidden, does fundamental damage to the cause of peace, like violations of other fundamental rights of the human person." 10

The absence or diminishing of religious liberty tend to foster tyranny through the suppression of individual liberty. This is because religious liberty is a safeguard against governmental encroachment of power over its citizens. The development of religious liberty emanating from the JudeoChristian tradition, well illustrates this. According to Adrian Karatnycky of Freedom House,

The correlation between Christianity and freedom at the end of the twentieth century is very strong...Christian countries, at this stage of human development, are about six times more likely to be free and democratic, as they are to be nondemocratic and suffer from serious abridgements in human rights. ${ }^{11}$

In another context Karatnycky declared,

Of the 81 countries that we rate as free in our survey, 74 are majority Christian. Of the seven free countries that are not majority Christian, one is Israel, which is part of the JudeoChristian civilization. Two others, Mauritius and South Korea, have very large Christian communities, and in some cases 
growing Christian communities, more than a third of their population. Of the four free countries that don't have strong relations to the Judeo-Christian tradition, one is Mali, which is predominately Muslim. Another is Taiwan, where nearly half the population is Buddhist. Another is Mongolia, which is traditional Buddhist. And finally there is Japan, which observes both the Buddhist and Shinto traditions. ${ }^{12}$

There has been a commitment to religious toleration in other traditions as well according to Ninan Koshy,

Twenty-three centuries ago King Ashoka, patron of Buddhism, recommended to his subjects that they should act in accordance with a principle of toleration. 'Acting thus, we contribute to our creed by serving others. Acting otherwise, we harm our own faith, bringing discredit upon the others. He who exalts his own belief, discrediting all others does so surely to obey his religion with the intention of making a display of it. But behaving thus, he gives it the hardest blows. And for this reason concord is good only in so far as all listen to each other's creeds and live to listen to them.' ${ }^{13}$

\section{THE VARYING RELATIONSHIPS BETWEEN CHURCH AND STATE}

Church and state have related in various ways in the history of the West. Philip Wogman ${ }^{14}$ offers four basic types of church-state relationships: 
1. Theocracy: the state is under the control of religious leaders or institutions for religious purposes.

2. Erastianism: the church when under the control of the state has been termed "Erastianism" (after the sixteenth-century Swiss German, Thomas Erastes).

3. Separation of church and state-friendly: religious and political institutions are legally separate but not hostile to each other.

4. Separation of Church and state-unfriendly: religious and political institutions are legally separate and in an antagonistic relationship.

Ancient, Medieval and Reformation Christianity generally vacillated between Wogaman's theocratic and Erastian categories. ${ }^{15}$ Post-reformation Christianity in the West generally has favored what Wogman has termed a friendly separation of church and state. In more recent years with the emergence of secularism and Marxism, an unfriendly separation of church and state has manifested itself. It is ironic that the language of "separation between church and state" does not appear in US Constitution or the First Amendment, but this phrase was part of the Constitution of the former U. S. S. R.:

In order to ensure to citizens freedom of conscience, the church in the U.S.S.R. is separated from the State, and the school from the church. Freedom of religious worship and freedom of anti-religious propaganda is recognized for all citizens." 16 
Yet in 1928, Anatolii Lunarchskii, a former Soviet Minister of Education offered this astute comment aimed at the governmental coercion of religious belief, "Religion is like a nail, the harder you hit it, the deeper it goes into the wood." 17

A 1986 UN study done by Elizabeth Odio Benito, the Special Rapporteur of the UN Commission on Human Rights, presented a more detailed taxonomy of church and state issues, identifying eight distinctive relationships between church and state $^{18}$ :

1. State religions.

2. Established churches.

3. Neutral or secular states as regarding religion.

4. No official religion.

5. Separation of church from state.

6. Arrangements with the Roman Catholic Church.

7. Protection of legally recognized religious groups.

8. Millet system, recognizing a number of religious communities.

With these general categories in mind, let us next summarize some of the leading biblical reasons for the Christian commitment to religious liberty.

\section{BIBLICAL CHRISTIANITY AND RELIGIOUS LIBERTY}

From a biblical view, freedom is a creation ordinance, that is, it is grounded in the fabric of reality by divine creation. This can be seen in Adam's relationship to God's rule. Adam, as God's image bearer, was given the freedom of personal choice 
to follow God or to disobey God's rule in the Garden of Eden. Adam in essence was given the right to be wrong. There were consequences to being wrong, but God did not prevent Adam's choice to set aside God's call upon his life.

Israel had a separation of religious rule from political rule. The tribe of Levi was the source for the priesthood. The tribe of Judah was the source for the monarchy. This enabled there to be a religious culture not totally dominated by the state. Further, Israel, although a theocracy especially in the era of the judges, nevertheless had a constitution, namely, the Ten Commandments. The most powerful Being in the universe bound Himself in covenant with His people. This covenant of God had implications for the covenant of His people with one another. These covenantal duties to God and to each other were thus summarized in the constitution of God's people, namely, the Ten Commandments. The first table of the Commandments or the law addressed religion. The second table of the law addressed justice. This structure suggested a distinction between "church" and "state" but this distinction did not mean that these entities were autonomous. Both church and state had authority that was limited by expressed duties. The two tables of the Ten Commandments implied a separation of powers between church and state and a limitation of the powers of each by expressed duties. Leviticus 25:10 pointed toward civil liberty when in the Jubilee year Israel was commanded to "Proclaim liberty throughout the land unto all the inhabitants thereof." This had the effect of restoring to individuals lost liberties that had occurred by debt and other mistakes. 
Early Christianity grew merely by preaching, persuasion and missions, that is, by the power of speech. This emphasizes the importance of free speech. When told not to speak any more in the name of Jesus Christ, the apostles declared in Acts 5:29, "We must obey God rather than man." Jesus' teaching authorized no use of the sword or the state's coercive power to advance his faith. Matthew 22:15-22 asserts that both Caesar and God have their respective prerogatives that must be properly addressed. Verse 22 declares, "Render to Caesar the things that are Caesar's, and to God the things that are God's." Jesus' Golden Rule taught in Matthew 7:12, "Do unto others as you would have them do unto you," when applied to the public square, creates freedom. One who does not want to be persecuted for his own faith should not persecute another for his faith.

Ultimately, then, Christianity seeks freedom not mere "toleration" or bare "harmony". There are several texts that advocate freedom in Scripture. ${ }^{19}$ The following are worth underscoring here:

a. Isaiah 61:1, "The Spirit of the Lord God is upon me...to proclaim liberty to the captives, and the opening of the prison to those who are bound."

b. John 8:32, "You will know the truth, and the truth will set you free."

c. 1 Corinthians 7:21, "If you can gain your freedom, avail yourself of the opportunity."

d. 2 Corinthians 3:17, "Where the Spirit of the Lord is, there is freedom" 
e. Galatians 5:1, "For freedom Christ has set us free; stand firm therefore, and do not submit again to a yoke of slavery.

Founding President of the United States, George Washington, emphasized to the Hebrew Congregation on August 17, 1790 that the Jewish people did not possess mere toleration under the new government, but full religious freedom:

It is now no more that toleration is spoken of, as if it was by the indulgence of one class of people, that another enjoyed the exercise of their inherent natural rights. For happily the government of the United States, which gives to bigotry no sanction, to persecution no assistance, requires only that they who live under its protection should demean themselves as good citizens, in giving it on all occasions their effectual support....May the children of the Stock of Abraham, who dwell in this land, continue to merit and enjoy the good will of the other inhabitants, while every one shall sit in safety under his own vine and fig-tree, and there shall be none to make him afraid. ${ }^{20}$

President George W. Bush on July 4, 2001 came to Independence Hall in Philadelphia to celebrate 300 years of Religious Liberty in Philadelphia and 225 years of American Independence. His remarks on this occasion recognized the connection between humanity's creation by God and America's experience of religious liberty: 
A wonderful country was born [July 4, 1776] and a revolutionary idea sent forth to all mankind: Freedom, not by the good graces of government, but as the birthright of every individual. Equality, not as a theory of philosophers, but by the design of our Creator. Natural rights, not for the few, not even for the fortunate, but for all people, in all times. ${ }^{21}$

\section{BASIC QUESTION OF RELIGIOUS LIBERTY: SHOULD THE GOVERNMENT PROTECT PEOPLE FROM RELIGIOUS "ERROR"?}

The issue of the government's role in protecting people from what is deemed to be religious error emerges in the English speaking world with John Wycliffe of Oxford University who lived in the 1400's. ${ }^{22}$ Often called "the morning star of the Protestant Reformation" he was first to translate the Bible into the English language. His followers became known as the "lullards" because of their whispering witness of their faith due to fear of persecution. As persecution mounted against his movement, Wycliffe's bones were exhumed, ground to dust and cast into the sea. Thus he was an object of the Roman Catholic inquisition even after his death. The issue at the heart of the inquisition was to root out religious error in order to preserve what was believed to be religious truth for the seemingly noble end of the salvation of human souls.

By the 1700's, after centuries of religious persecution in England, this perspective began to change. John Locke (16321704), a British Christian philosopher, argued in A Letter Concerning Toleration, 
...the care of souls is not committed to the civil magistrate, any more than to other men. It is not committed unto him, I say, but God; because it appears not that God has ever given any such authority to one man over another, as to compel any one to his religion. ${ }^{23}$

A portion of his concluding prayer in A Letter Concerning Toleration reflects a growing understanding of the distinction between the work of the state in civil matters and the work of the church in the concern for spiritual salvation,

God Almighty grant ... that the Gospel of Peace may at length be preached, and that civil magistrates, growing more careful to conform their own consciences to the law of God and less solicitous about the binding of other men's consciences by human laws, may, like fathers of their country, direct all their counsels and endeavours to promote universally the civil welfare of all their children, ... and that all ecclesiastical men . . . walking peaceably and modestly in the apostles' steps ... may apply themselves wholly to promote the salvation of souls. ${ }^{24}$

American founding father Thomas Jefferson's rejected the notion that the force of government should be used to protect people from spiritual error: "It is error alone which needs the support of government. Truth can stand by itself." 25 In Jefferson's mind, the quest for spiritual truth requires the risk of religious error, because truth will ultimately prevail and be known. 
Twentieth century Christian theologian Reinhold Niebuhr explained,

The history of free societies proves conclusively that the dictum that "error" does not have the same rights as the "truth" is a very dangerous one, not because it is not possible to distinguish between truth and error, but because in the endless conflicts of interest in a society, it is dangerous to give any interest group the monopoly to define the "truth". So much truth rides into history on the back of error, and so much "error" is but a neglected portion of the whole truth, which is an error only in the degree that it has been overemphasized in order to get itself heard and when acknowledged and restored to the whole, ceases to be an error and becomes a part of the truth. ${ }^{26}$

Thomas Jefferson as Governor of Virginia, along with the help of fellow Virginian James Madison, established the commitment to Religious liberty in his state and thus helped it take root in America. Jefferson's 1786 "Act for Establishing Religious Freedom" declares,

Whereas Almighty God hath created the mind free; that all attempts to influence it by temporal punishments or burthens, or by civil incapacitations, tend only to beget habits of hypocrisy and meanness, and are a departure from the plan of the Holy author of our religion, who being Lord both of body and mind, yet chose not to propagate it by coercions on either, as was in his Almighty power to do; that the impious presumption of legislators and rulers, civil as well as 
ecclesiastical, who being themselves but fallible and uninspired men, have assumed dominion over the faith of others, setting up their own opinions and modes of thinking as the only true and infallible, and as such endeavouring to impose them on others, hath established and maintained false religions over the greatest part of the world, and through all time; ....Be it enacted by the General Assembly, That no man shall be compelled to frequent or support any religious worship, place or ministry whatsoever, nor shall be enforced, restrained, molested, or burthened in his body or goods, nor shall otherwise suffer on account of his religious opinions or belief; but that all men shall be free to profess, and by argument to maintain, their opinion in matters of religion, and that the same shall in no wise diminish, enlarge, or affect their civil capacities. ${ }^{27}$

Jefferson's concern to protect the conscience is seen in his famous letter where he writes of the "wall of separation between Church and State". In his letter to a committee of the Danbury Baptist Association, Connecticut, January 1, 1802, Jefferson declared:

...Believing with you that religion is a matter which lies solely between man and his God, that he owes account to none other for his faith or his worship, that the legislative powers of government reach actions only, and not opinions, I contemplate with sovereign reverence that act of the whole American people which declared that their legislature should "make no law respecting an establishment of religion, or prohibiting the free exercise thereof," thus building a wall of separation between 
Church and State. Adhering to the expression of the supreme will of the nation in behalf of the rights of conscience, I shall see with sincere satisfaction the progress of those sentiments which tend to restore to man all his natural rights, convinced he has not natural right in opposition to his social duties... ${ }^{28}$

\section{PERSECUTION FROM THE ANCIENT CHURCH TO PROTESTANTISM}

The story of religious liberty in the West and its uniqueness in world history cannot be understood without an appreciation of the rise of the Protestant tradition beginning in the sixteenth century as well as the religious persecution that has been the norm for most nations throughout history. Western civilization includes a continual display of religious persecution. ${ }^{29}$

Our study begins with a survey of religious persecution in the history of the West. It then develops how different branches of the Protestant faith helped to establish the first expressions of religious liberty in North America, with its culmination in the First Amendment of the United States Constitution.

Religious Persecution in the Ancient and Medieval Church..$^{30}$

The Roman Empire granted legitimacy to some religions but not to others as reflected in the titles of Religio Licita and Religio Illicita. The resulting persecution of illegitimate religions led to profound suffering for Jews and early Christians. The pre-conversion Saul of Tarsus recorded in the biblical book of 
Acts of the Apostles reflects a spirit of persecution of early Christians. Yet, as the early church father Tertullian (c.160/70c.215/20) wrote, "The blood of the martyrs is the seed of the Church." 31 The unflinching testimony of those martyred for their faith created new believers even more committed to sustaining the growth of the church.

The toleration of Christianity (AD 313) by Emperor Constantine (c.274-337) and the subsequent establishment of Christianity as the religion of the Roman Empire in the Byzantine Era resulted in the use of the coercive power of the state to further the Christian faith. Sadly, triumphant Christianity, the religion formerly persecuted, began to persecute others, including those within the Christian fold who disagreed with prevailing beliefs. Ninan Koshy writes,

Constantine's Edict of 313 provided for individual freedom of conscience, for full rights to Christianity on equality with other recognized religions and for the restoration of church property which had been confiscated. Favour led to privilege, which turned to prestige; and the church soon became very powerful. Then the church and the state turned on the heretics. The codes of Theodosius and Justinian forbade heretics to build churches, to assemble for religious purposes or to teach their doctrines even in private. They were denied rights of bequest, inheritance, even of contract. Death was prescribed for those who lapsed from Christianity into pagan rites.... some of these measures in the codes of Theodosius and Justinian appealed to medieval and early modern state on into the Reformation. ${ }^{32}$ 
Further M. Searle Bates points to the historic attempts to justify persecution by appeal to the Bible,

Already men were at work to support from the scriptures the measures of compulsion and punishment which they desired to inflict by state authority or other means. The Old Testament was then and thereafter to be searched for passages prescribing death penalties for idolatry, blasphemy and apostasy which could be inflicted upon heresy as well. The New Testament provided little material penalties but was richer in the content and destructive support of strict orthodoxy. From the two Testaments taken together, the dogmatist, the bigot, the man of faction, the literalist, the bureaucrat, the sadist have been able to justify their will, that day until now. ${ }^{33}$

The Medieval Period saw the long hegemony of the Church over the European State. As noted above, this resulted in protests by political theorists such as John Wycliffe (c.1329-1384). The issue at the heart of the inquisition was to root out religious error in order to preserve what was believed to be religious truth for the noble end of the salvation of human souls. John Hus (13731415), a learned man of Prague, was burned at the stake 600 years ago in 1415 for criticizing the wrongs committed by those in authority in the Church. Many others met a similar fate. 
The General Reality of Religious Persecution in the Era of the Protestant Reformation.

The story of Martin Luther reveals that he was liable to persecution and death from the Roman Catholic powers due to his non-conventional convictions regarding the Word of God. At the Imperial Diet of Worms on April 18, 1528 Luther declared: "Unless I am convicted by Scripture and plain reason-I do not accept the authority of popes and councils, for they have contradicted each other-my conscience is captive to the Word of God. I cannot and I will not recant anything, for to go against conscience is neither right nor safe. Here I stand, I cannot do otherwise. God help me, Amen." 34

The Diet of Worms was a specially called imperial congress where Luther defended the doctrines that were at the heart of the Reformation. The Church and Emperor wanted Luther to recant his teachings. Due to his excommunication by the church before Luther was invited to Worms, he had already in essence been declared a heretic. On his journey to Worms, Luther was welcomed in all of the towns he went through, preaching along the way. He arrived in Worms on April 16 and was also cheered and welcomed by the people. Luther appeared before the Emperor twice. At each time he was told to recant. But Luther refused since he did not see any evidence that his teachings were unbiblical.

When Luther was dismissed, he was not arrested because he had a letter of safe conduct which guaranteed three weeks of safe travel. He left for home on April 25. But when Luther and his protecting princes departed, the emperor imposed an 
Imperial Act wherein Luther was declared an outlaw. This meant that he could be slain by anyone without fear of reprisal. So Elector Friedrich the Wise had Luther kidnapped on May 4th to assure Luther's safety. Luther was taken to the Wartburg Castle where he remained for ten months, where in three months' time he had translated the New Testament into German.

But the power of the written word and of a free press in changing the reality of religious persecution was soon recognized by Luther and reforming writers. From Martin Luther in Germany to John Foxe in England, the power of the printed word became a tool to challenge religious persecution and unbridled power: "As his rift with the Vatican grew, Luther soon came to embrace the new technology as 'God's highest and extremest act of grace' by which the Gospel was 'driven forward'; or as John Foxe would later put it in his Book of Martyrs: 'God hath opened the press to preach, whose voice the pope is unable to stop with all the puissance of his triple crown.'" 35 So the struggles between the Catholic tradition and its reforming rivals increased. At the beginning of the Seventeenth Century, Europe was engulfed in what came to be known as the "wars of religion".

The violence and sufferings resulting from the absence of religious liberty that spread throughout Europe during this era was captured by English Puritan poet John Milton's sonnet entitled "On the Late Massacre in Piedmont" in 1655. It tells the story of the Waldensians, a religious group that started around 1210 and continues until today. Their flight from persecution 
began in the 1200's. They found a safe haven in the Swiss and Italian Alps where they clung to their religious beliefs grounded on the Bible and especially the gospels. Later in the early seventeenth century they joined the Reformed Churches that followed the teachings of John Calvin. So, their sufferings intensified as they were now identified as Protestants. John Milton's lyrical lament reveals the atrocities perpetrated on the Waldensians and that their persecution had become known as far away as England:

Avenge, O Lord, thy slaughtered saints, whose bones Lie scattered on the Alpine mountains cold;

Even them who kept thy truth so pure of old, When all our fathers worshiped stocks and stones, Forget not: in thy book record their groans Who were thy sheep, and in their ancient fold Slain by the bloody Piedmontesse, that rolled Mother with infant down the rocks. Their moans The vales redoubled to the hills, and they

To heaven. Their martyred blood and ashes sow

O'er all the Italian fields, where still doth sway The triple Tyrant; that from these may grow A hundredfold, who, having learnt thy way, Early may fly the Babylonian woe. ${ }^{36}$ 


\section{THE REFORMED TRADITION: JOHN CALVIN AND RELIGIOUS LIBERTY.}

The relationship between church and state that developed in the early Reformation era of religious conflict was summarized by the Latin maxim "Cuius Regio, Eius Religio", "Whose Region, His Religion". In other words, only the King's conscience in matters of religion would be recognized. The persecuted, various scholars as well as religious leaders began to wonder how the view that religious liberty belonged only to the powerful could be changed, so all could share in its blessings? This was especially true of the French Huguenots, Protestant followers of Calvin, who greatly suffered under Roman Catholic opposition and persecution.

Calvin's theology developed clear conceptions of the relationship of church and state. In the 1543 edition of his Institutes, Calvin declared his preference for the republican form of government:

For if the three forms of government which the philosophers discuss be considered in themselves, I will not deny that aristocracy, or a system compounded of aristocracy and democracy (vel aristocratian vel temperatum ex ipsa et politia statum) far excels all others. ${ }^{37}$

Calvin's theology separated church and state, but assumed and provided for their mutual interaction. ${ }^{38}$ For him alienation between them would have spelled disaster. John McNeill states, 
His concentration on Biblical studies and his labor and care for the church did not eradicate his political interest but gave to it a new dimension; the magistrate became, for man's earthly order of life, a vicar of God. It need not surprise us to find that from his Commentary on Seneca's Treatise on Clemency of 1532 until that hour in 1564 when from his deathbed he urged the magistrates of Geneva so to rule as to 'preserve this republic in its present happy condition,' his writings are strewn with penetrating comments on the policies of rulers and illuminating passages on the principles of government. ${ }^{39}$

An eminent Catholic historian, E. Jarry, emphasizes that in the political domain, Calvinist ideas are at the origin of the revolution which from the $18^{\text {th }}$ to the $19^{\text {th }}$ centuries gave birth and growth to the parliamentary democracies of Anglo-Saxon type. ${ }^{40}$ Philip Schaff, church historian, wrote: "The principles of the Republic of the United States can be traced through the intervening link of Puritanism to Calvinism, which, with all its theological rigor, has been the chief educator of manly characters and promoter of constitutional freedom in modern times." 41 Thus Calvin helped to foster the development of the republican form of government with its emphasis on freedom.

However, even though exiled and constantly endangered because of his own deep faith, Calvin supported the civil magistrate of Geneva, Switzerland in the heresy trial that led to the execution of the Spanish physician and anti-Trinitarian Miguel Servetus (1511-1553). In 1562, in the midst of a religious war in France, a small yet significant anonymous book was 
published entitled Advice to a Desolate France. Written by a Protestant professor of Greek at the University of Basel, Sebastian Castellio (1515-1563), the book was considered "full of error" by a Church Council at the time and ordered to be destroyed. Only four copies are known to have survived.

Castellio argued that the "forcing of consciences" in matters of religion created the maladies of war-torn France:

I find that the principal and effective cause of your malady, that is to say of the sedition and war which torment you, is the forcing of consciences...As one had for a long time forced and tried to force the consciences of the Evangelics ... they themselves, in their treaty entered into at Orleans, stress sufficiently clearly that they are fighting for religion, considering that of the three reasons for which they say they are taking up arms, the first is the Honour of God. As such, one must conclude that the cause of this war is the forcing of consciences... Consequently, ... the advice which I am giving you...is that you should cease the forcing of consciences and stop persecution, not to mention the killing of a man because of his faith....

Castellio's advice to France to "cease the forcing of consciences and stop persecution, not to mention the killing of a man because of his faith" fell on deaf ears.

John Calvin had earlier argued for religious liberty and had written, "It is criminal to put heretics to death. To make an end of them by fire and sword is opposed to every principle of humanity." But upon assuming leadership in Geneva, he 
altered his view in response to the disorder that threatened Geneva by those who opposed his strong theological perspectives. This inconsistency was trenchantly spotlighted by Castellio, who wrote,

Let all of my readers compare Calvin's original declaration with his writings and his deeds today and it will become plain that his present and his past are as unlike one another as light and darkness. Because he has had Servetus put to death, he now wishes to execute in like manner all who differ from himself. $\mathrm{He}$, the lawmaker, repudiates his own law, and demands the death penalty for dissentients....42

Calvin's theological followers ultimately returned to his earlier view that opposed the execution of heretics. In fact, nineteenth century European Calvinists, led by Emile Doumergue, erected an "expiatory monument" at the site where Servetus was burned. ${ }^{43}$ So Calvin was a man in the middle between Medieval Constantinan persecution and the advancing concern for liberty. ${ }^{44}$

\section{THE FRENCH HUGUENOTS' CONTRIBUTIONS TO RELIGIOUS LIBERTY.}

The Huguenots, or French Protestant followers of Calvin, faced episodic war and constant overt or indirect persecution as they and Catholics opposed each other's religious beliefs and social and political policies. Philippe Duplessis-Mornay was a distinguished Huguenot theologian and statesman who moved 
Calvinistic thought forward to political liberty. Mornay's studied law at Heidelberg, and Biblical languages at Padua. He became active in the political, military and theological concerns of the Huguenot movement. He escaped the St. Bartholomew's Day Massacre by seeking refuge in England. Upon return to France he closely served Henry IV, the Protestant King who ultimately became the Catholic King of France by converting to Catholicism.

Mornay's leadership was broadly recognized, and earned the epithet of the "Huguenot pope". With King Henry's abjuration of the Protestant faith, Mornay could no longer serve the Catholic monarch. Leaving public service he joined the faculty of the Academy of Saumur. Mornay's legacy on the development of political liberty in the West was substantial:

From the being of God, to whom all men owe respect, Mornay inferred civil rights and liberties. The authority of kings was limited by the authority of God.... For Mornay, the sovereign was only the supreme delegate of the nation. Beza came out with the concept of a contract. It was adopted by all Huguenot writers on current public topics, but Mornay made it basic in politics: kingship was founded on a contract whose conditions were dictated by the people. Mornay ... fixed some Huguenot political concepts which passed abroad and are to be found at the roots of our modern democracies. ... not all ... had clearly perceived the principle of separation of powers, but Mornay had certainly suspected its importance. He claimed excusive legislative authority for the States General and executive power 
for the king. Whereas he may not have perfectly understood this principle, Mornay caught sight of the fact that if the legislative power is the same as the executive, there are then no bounds to the executive power. The only safeguard of the liberty and security of persons is to be found in the separation of political powers. With imposing gravity, Mornay ... set forth the four great principles: sovereignty of the nation, political contract, representative government, and the separation of powers that really makes up all our modern constitutions. ${ }^{45}$

Huguenot theologian Moses Amyraut (1596-1664) would later teach at the theological school in Saumur, France which had been so strongly marked by the legacy of Mornay. ${ }^{46}$ Some years later, Amyraut would welcome William Penn as a student. ${ }^{47}$ It is interesting to note that Amyraut was unwilling to kneel before the French King during a scheduled appearance before the king to state the French Reformed Church's complaints concerning alleged violations of the Edict of Nantes. Amyraut pointed out that this sort of humility was contrary to the terms of the Edict. After a fifteen day stand-off, Cardinal Richelieu and the King acquiesced to Amyraut's insistence on standing in the King's presence, as was the custom when Catholic clergy spoke to the King. He thereby won the lasting respect of the Cardinal. ${ }^{48}$

The Edict of Nantes was negotiated by Huguenot DuPlessis Mornay and French King Henry IV and signed on April 13, 1598. The Huguenots would later lose these liberties by the Revocation of the Edict of Nantes on October 22, 1685. Their ongoing persecutions brought Huguenot immigrants to 
America including the families and ancestors of American patriots Paul Revere, John Jay, Elias Boudinot, and Alexander Hamilton.

\section{THE ENGLISH PURITANS' AND NON-CONFORMISTS' ROLES IN DEVELOPING RELIGIOUS LIBERTY.}

One impetus for the development of religious liberty was the experience of the English Puritans and Non-conformists. They emerged in the era of the reformation of the English Church and after the English Civil War that was fought between Protestant Anglicans loyal to the King and Protestant Puritans. The Puritan army was victorious and ultimately beheaded King Charles I. Some twenty years later, the monarchy was restored under Charles II along with the reestablishment of the Anglican Church. Puritans and other nonconforming Protestants, unable to support the Anglican way of worship, faced the return of state sanctioned persecution. The Anglican Puritans hoped to see the Church purified, and so their opponents dubbed them "Puritans". The name of contempt stuck and was embraced as a badge of honor.

A pre-English Civil War Non-Conformist who advocated religious liberty was Thomas Helwys. Richard Groves writes,

In 1612 Thomas Helwys, an English country gentleman whose theological and ecclesiological interests had led him to identify first with the Puritans, then with the Separatists, and finally, along with John Smyth, to help establish the first Baptist church, returned to England from exile in Holland. With him 
Helwys brought a manuscript titled 'The Mystery of Iniquity,' in which he set forward for the first time in English the notion of liberty of conscience, or freedom of religion. Shortly after settling in Spittalfield, near London, Helwys published his book. Though it was hardly a bombshell at the time of publication, it probably cost Helwys his freedom and perhaps even his life. ${ }^{49}$

Helwys explained why forcing a man's conscience in religious matters was both tyrannical and illogical,

And we bow ourselves to the earth before our lord the king in greatest humbleness, beseeching the king to judge righteous judgement herein, whether there be so unjust a thing and of so great cruel tyranny under the sun as to force men's consciences in their religion to God, seeing that if they err, they must pay the price of their transgressions with the loss of their souls. Oh, let the king judge, is it not most equal that men should choose their religion themselves, seeing they only must stand themselves before the judgement seat of God to answer for themselves, when it shall be no excuse for them to say we were commanded or compelled to be of this religion by the king or by them that had authority from him ${ }^{50}$

Thomas Helwys wrote again in 1615 another work entitled Objections: Answered by way of Dialogue, wherein is proved By the Law of God; By the law of our Land; And By his Majesties many testimonies, That no man ought to be persecuted for his religion..$^{51}$ 
Because of the persecution of religion, John Bunyan's (1628-1688) famous allegory, Pilgrim's Progress $(1678,1684)$, was written in jail (intermittently from 1660 to 1672) after the restoration of the monarchy and the Anglican Church. Bunyan as a conscientious Non-Conformist could not submit to the liturgy prescribed by the law of England. He was convicted as a criminal, even though he sought to be a devout Christian. In 1666, the middle of his prison-time, Bunyan wrote Grace Abounding to the Chief of Sinners, in which he declared, "The Almighty God being my help and shield, I am determined yet to suffer, if frail life might continue so long, even till the moss shall grow upon my eyebrows, rather than violate my faith and principles." John Owen, a powerful preacher and the bestknown of all the Puritan writers, said that he would gladly have exchanged all his learning for Bunyan's power of touching men's hearts. ${ }^{52}$

The English Puritans, generally ordained clergymen of the Anglican Church, also wrestled with the idea of the liberty of conscience. This is evident in the studies of conscience by William Perkins (1558-1602), William Ames (1576-1633) and John Owen (1616-1683). ${ }^{53}$ The Puritan conscience struggled with conformity to the English Church's government and worship and sought when possible to reform it along more biblical lines. The conflict between Anglicans and Puritans led to the English Civil War.

Thomas Jefferson's remarks in his Notes on the State of Virginia, also recognized the Anglican persecution of Presbyterians in their North American colonies: 
The first settlers in this country were emigrants from England, of the English church, just at a point of time when it was flushed with complete victory over the religious of all other persuasions. Possessed, as they became, of the powers of making, administering, and executing the laws, they shewed equal intolerance in this country with their Presbyterian brethren, who had emigrated to the northern government. ${ }^{54}$

The need for religious liberty in America was discerned by John Owen and other nonconformists in England. The reports received in England of persecution by American Congregationalists of Baptists in their midst, made the complaint against religious persecution in England by English Congregationalists less compelling, or even hypocritical. So on March 25, 1669, fearing the loss of some gains in religious liberty recently won, Dr. Owen along with twelve others sent a letter to the Governor of the Colony of Massachusetts. The occasion was the formation of a Baptist Church in Boston on May 28, 1665 which admitted into membership people who had been excommunicated by the Congregational Church, the established state church. The General Court was afraid "that matters might grow from small beginnings into a new 'Munster tragedy' and so they passed various laws for the restraint of the Baptists. These proved to be an embarrassment to the Nonconformists in Old England and so the letter came to be written, but it produced no immediate relaxation of the laws." 55 Owen and others wrote, 
We shall not here undertake (in the least) to make any apology for the persons, opinions and practices of those who are censured among you. You know our judgement and practice to be contrary unto theirs, even as yours; wherein (God assisting) we shall continue to the end. Neither shall we return any answer to the reason of the reverend elders, for the justification of your proceedings, as not being willing to engage in the management of any the least difference with persons whom we so much love and honour in the Lord. But the sum of all which at present we shall offer to you is, that though the court might apprehend that they had good grounds in general warranting their procedure (in such cases) in the way wherein they have proceeded, yet that they have any rule or command rendering their so proceeding indispensably necessary, under all circumstances of fines or places, we are altogether unsatisfied;... We leave it to your wisdom to determine whether, under all these circumstances, and sundry others of the like nature that might be added, it be not advisable at present to put an end unto the suffering and confinements of the persons censured, and to restore them to their former liberty. You have the advantage of truth and order; you have the gifts and learning of an able ministry to manage and defend them; you have the care and vigilancy of a very worthy magistracy to countenance and protect them, and to preserve the peace; and (above all) you have a blessed Lord and Master, who hath the keys of David, who openeth and no man shutteth, living for ever to take care of his own concernments among his saints; and assuredly you need not be disquieted, though some few persons (through 
their own infirmity and weakness, or through their ignorance, darkness and prejudices) should to their disadvantage turn out of the way, in some lesser matters, into by-paths of their own. We only make it our hearty request to you, that you would trust God with his truth and ways so far, as to suspend all rigorous proceedings in corporal restraints or punishments, on persons that dissent from you and practise the principles of their dissent without danger, or disturbance to the civil peace of the place..$^{56}$

\section{THE ENGLISH CIVIL WAR AND THE WESTMINSTER CONFESSION'S STATEMENT ON CHURCH AND STATE.}

The Westminster Assembly was an ecclesiastical synod called by the Pro-Puritan British government to reform the church. The historical context of the Westminster Confession enables us to understand the Confession's doctrine of the relationship of Church and State.

The historical forces that led to the Westminster Assembly began in 1625 when Charles I ascended to the English throne. Charles I continued his father James I's religious persecution of the Puritans in England and the Presbyterians in Scotland. But Charles met such strong opposition in Scotland to his program of religious unification that he eventually had to convene the Parliament to raise men and resources to govern the unruly Scots. In fact, in 1637, the Scottish National Covenant was signed, that abolished the Anglican Episcopal form of church government. 
But to the King's surprise and anger, the English people elected a Parliament with a majority of Puritans, which the King then dissolved, calling for another election. The second Parliament, however, had an even greater number of Puritans. But when Charles ordered it to dissolve, Parliament refused, forcing Charles to field an army to compel the Parliament to obey him.

Soon the Puritan Parliament called upon the Scottish Presbyterians to join them. Their army led by Oliver Cromwell defeated Charles I, who having been convicted as a tyrant, was beheaded in 1649. The Commonwealth was established and Oliver Cromwell became the Lord Protector of England and Scotland. Cromwell ruled from 1648 until 1660.

During the more than five years of civil war, the Westminster Assembly convened by Parliament, sought to reform the Church of England. They began their work at the Westminster Abbey in London, on July 1, 1643. After giving up the attempt to rework the Anglican Church's Thirty-Nine Articles of Religion, they began the production of a new Confession of Faith. The Westminster Confession of Faith was finished by year's end in 1646, and approved by Parliament in 1648.

The victorious Puritans, however, were not prepared to recognize religious liberty for all since they desired to replace one Protestant State Church with another Protestant establishment. Nevertheless, the Puritan theologians had begun to wrestle with the necessity of providing for the liberty of 
conscience. This is evident in Chapter XX of The Westminster Confession of Faith concerning the liberty of conscience:

God alone is Lord of the conscience, and hath left it free from the doctrines and commandments of men which are in anything contrary to his Word, or beside it, in matters of faith or worship. So that to believe such doctrines, or to obey such commandments out of conscience, is to betray true liberty of conscience: and the requiring of an implicit faith, and an absolute and blind obedience, is to destroy liberty of conscience, and reason also (XX.2).

Yet in Chapter XXIII, in spite of Chapter XX's explicit commitment to the liberty of conscience, the Assembly reaffirmed the historic view that the magistrate oversees the theology of his state church and thus the King governs in matters of religion:

The civil magistrate may not assume to himself the administration of the Word and sacraments, or the power of the keys of the kingdom of heaven; yet he hath authority, and it is his duty, to take order that unity and peace be preserved in the Church, that the truth of God be kept pure and entire, that all blasphemies and heresies be suppressed, all corruptions and abuses in worship and discipline prevented or reformed, and all the ordinances of God duly settled, administered, and observed. For the better effecting whereof, he hath power to call synods, to be present at them and to provide that 
whatsoever is transacted in them be according to the mind of God (XXIII. 3).

This position was consistent with the fact that the Westminster Assembly had been called to do its work of reformation by the will of Parliament.

With Cromwell's death, no one was able to lead Parliament and Charles II ascended to his father's throne. Charles II, who possessed Roman Catholicism sympathies, sought to avenge his executed father, and returned to the earlier practice of persecuting Puritans, Non-Conformists and Presbyterians. The Anglican persecution of Scottish Covenanters lasted from 1665 to1688 until the Act of Toleration was passed with the accession of Protestants William and Mary to the throne. In 1689, The Act of Toleration was passed in England, permitting a greater degree of religious liberty in England. The Act permitted Nonconformists the freedom of worship as well as their own places of worship if they pledged oaths to the throne and rejected the Roman Catholic doctrine of Transubstantiation. So while Protestant dissenters from the Church of England were included, Catholics were not. The Church of Scotland remained Presbyterian.

During this time, John Locke, a professor and philosopher at the University of Oxford, began to ponder religious liberty. In 1689, the year of adoption of the Act of Toleration, he published A Letter Concerning Toleration. He concluded that religious persecution was inconsistent with the Christian Gospel. He wrote, "The toleration of those that differ from 
others in matters of religion, is so agreeable to the Gospel of Jesus Christ, and to the genuine reason of mankind, that it seems monstrous for men to be so blind as not to perceive the necessity and advantage of it in so clear a light."

Locke argued for religious freedom in three essays on toleration. However, he excepted atheism and Roman Catholicism from his plea for toleration, not on religious grounds, but due to state policy. Locke thought that Roman Catholics were dangerous to the public peace because a Catholic professed allegiance to a foreign prince. The atheist was excluded because, on Locke's view, the existence of the state depends upon a contract, and the moral obligations of contracts, as of all moral law, depend upon the divine nature. Slow progress was being made in the direction of religious liberty.

\section{ROGER WILLIAMS AND THE BEGINNINGS OF RELIGIOUS LIBERTY AT PROVIDENCE PLANTATION IN RHODE ISLAND}

Flight from the Wars of Religion and Religious persecution prompted colonization of the New World by religious groups. The Pilgrims and Puritans established the New England Congregationalists. Roman Catholics settled in Maryland. South Carolina was the home of the French Huguenots. Colonies in search of economic growth also brought their religious faiths. New York welcomed Swedish Lutherans and Anglicans while Virginia established the Anglican Church. But the liberty of conscience longed for in 
the New World for the persecuted was not granted to others: New England persecuted Quakers, Baptists; Virginia persecuted Quakers, Baptists.

Colonial America's immigrants' differing backgrounds necessitated a government that tolerated diverse religious views. The governor of the royal colony of New York reported in 1687 concerning the religious situation there:

New York has first a chaplain, belonging to the fort, of the Church of England; secondly, a Dutch Calvinist; thirdly, a French Calvinist; Fourthly, a Dutch Lutheran. Here be not many of the Church of England; few Roman Catholics; abundance of Quaker preachers, men and women especially Singing Quakers, Ranting Quakers, Sabbatarians, AntiSabbatarians; some Anabaptists; some Jews, in short, of all sorts of opinion there are some, and the most part none at all. ${ }^{57}$

Religious liberty in England, however, was nearly non-existent. James Hutson explains,

Puritan ministers who refused to conform were fired from their pulpits and threatened with "extirpation from the earth" unless they and their followers toed the line. Exemplary punishments were inflicted on Puritan stalwarts; one zealot, for example, who called Anglican bishops "Knobs, wens and bunchy popish flesh," was sentenced, in 1630, to life imprisonment, had his property confiscated, his nose split, an ear cut off, and his forehead branded S.S. (sower of sedition). ${ }^{58}$ 
The spirit of religious persecution carried over to the new world. Thomas Jefferson wrote of Anglican and Presbyterian persecution in the colonies in his Notes on the State of Virginia,

The first settlers in this country were emigrants from England, of the English church, just at a point of time when it was flushed with complete victory over the religious of all other persuasions. Possessed, as they became, of the powers of making, administering, and executing the laws, they shewed equal intolerance in this country with their Presbyterian brethren, who had emigrated to the northern government. ${ }^{59}$

Rhode Island, however, was the first experiment in religious liberty. It was established with the planting of the Providence Plantation by Roger Williams in 1636. Williams had been persecuted in New England for his Baptist beliefs. ${ }^{60}$ In a deed of 1661, Williams stated his purpose in establishing his colony: "I desired it might be for a shelter for persons distressed for conscience." Subsequently, the Baptist Confessions of Faith developed a strong emphasis on the "soul liberty" of believers and emphasized the separation of Church and State.

Adherents of various religious beliefs joined Williams, where they too could be protected. Williams offered three positions on religious liberty: "That forced worship stinks in God's nostrils, that it denies Christ Jesus yet to come; and that in these flames about religion, there is no other prudent, Christian way of preserving peace in the world but by permission of differing consciences." ${ }^{61}$ 
In a letter to the Town of Providence dated January 1655, Roger Williams gave an illustration of his conception of the liberty of conscience in a commonwealth,

There goes many a ship to sea, with many hundred souls in one ship, whose weal and woe is common, and is a true picture of a commonwealth or a human combination or society. It hath fallen out sometimes that both Papists and Protestants, Jews and Turks may be embarked in one ship; upon which supposal I affirm that all the liberty of conscience that ever I pleaded for turns upon these two hinges-that none of the papists, Protestants, Jews or Turks be forced to come to the ship's prayers or worship, nor compelled from their own particular prayers or worship, if they practice any. I further add that I never denied that, notwithstanding this liberty, the commander of this ship ought to command the ship's course, yea, and also command that justice, peace, and sobriety be kept and practiced both among the seamen and all the passengers. ${ }^{62}$

Soon, others began to stake their claim for religious liberty in William's Providence Plantation. Anne Hutchinson (1591-1643) was a daughter of a preacher and a Biblical scholar in her own right. She challenged the Boston religious community composed then of Calvinistic Congregationalists by holding Bible studies for women, which then expanded to include magistrates and scholars. ${ }^{63}$ What started as questioning of the authority of the Congregational Church grew into a schism threatening the political stability of the Boston colony. 
Excommunicated and banished from Boston, Hutchinson was killed by Indians in 1643. She has been credited by some with being the first American woman to lead the public fight for religious diversity and female equality. A memorial in her honor reads in part "Banished from the Massachusetts Bay Colony in 1638 Because of her Devotion to Religious Liberty." This first successful effort at religious liberty was to be followed by the extraordinary colony of Pennsylvania established by another minister, William Penn.

\section{WILLIAM PENN: VISIONARY OF RELIGIOUS LIBERTY.}

William Penn was baptized in All Hallows by the Tower in London on October 23, 1644, the son of William and Margaret Penn. His father would become an admiral under Charles II. William Penn fills a dramatic role in the development of religious liberty.

Raised an Anglican, he attended Christ Church College in Oxford at the age of sixteen, where the Puritan divine Dr. John Owen (1616-1683) was dean and John Locke (1632-1704), a Christian philosopher attempting to find a rational middle ground between the doctrine of the established State Church and the unbelief of the radical enlightenment, was a Fellow. Also during this time Penn went to hear Thomas Loe (d. 1688), a fiery Quaker preacher, sermonize the new gospel of the Society of Friends.

Penn began to attend worship services at the home of Dr. Owen after Owen was ejected as Dean following the restoration of the King and the Anglican Church. Christ College began to 
require the use of the Book of Common Prayer in its chapel services, and the wearing of the surplice, a garment used by the Anglican clergy. Penn bristled under the new religious discipline at Oxford, and was eventually expelled for "rioting" with other students in the quadrangle.

Furious, Penn's father sent him to France where he spent some time at the Royal Court in Versailles. During this time, Penn was forced into a sword duel in Paris, which he won. Having taken the sword from his opponent, he allowed him to live. Penn later remarked that the whole incident started over a perceived insult because Penn had unwittingly failed to tip his hat to the man earlier in the day. Penn later mused, "Was a man's life worth a hat?" Penn later joined the Quakers who by conviction in this era refused to tip their hats to anyone, even the King, since they believed that this was an expression of worldly vanity.

Leaving Paris, he traveled to Saumur, France. There he lived with and studied under the illustrious French Reformed theologian, Moses Amyraut (1596-1664). Here Penn experienced personally under the Edict of Nantes the attempts by the French Huguenots to enjoy religious freedom in a tenuous toleration of their faith by the Crown that supported a contrary state religion. The theological school in Saumur, France, was where the distinguished Huguenot statesman and advocate of religious liberty, Philippe Duplessis-Mornay, taught. Penn would not have known Mornay as the Huguenot leader had passed away over twenty years before. But Penn would have known of Mornay's legacy. 
Upon returning home, Penn studied law at Lincoln Inn in London, and experienced the great suffering and pain caused by the Black Death of 1665 and the great London fire of 1666 . Penn even entered into naval combat as he served for a time on ship. But he once again encountered Thomas Loe and heard Loe's sermon on the theme, "There is a faith which overcomes the world, and there is a faith which is overcome by the world." Penn left this meeting as a confirmed Quaker, and by doing so became a pacifist, hanging up his well-used sword once and for all. His father could not break Penn's convictions, and finally drove him from home, although Penn's mother continued to assist him with his living expenses.

Penn became a preacher for the Quakers, then a despised sect, and generally viewed as a heretical movement that replaced traditional worship elements by the inner light of the Holy Spirit. His preaching of these beliefs and questioning of other key Protestant and historic doctrines ultimately led to his imprisonment in the Tower of London. Here Penn wrote his classic work entitled, "No Cross, No Crown," based on the last words he had heard from his mentor Thomas Loe upon his deathbed.

It was during these days of imprisonment that he developed his dream of a place where freedom of conscience in regard to religion would be maintained. He later noted: "I abhor two principles in religion and pity them that own them; the first is obedience to authority without conviction; and the other is destroying them that differ from me for God's sake. Such a religion is without judgment, though not without teeth." 
After nine months of experiencing the "teeth" of a stateestablished religion, Penn was released from the Tower, even more convinced that "we must give the liberty we ask...we cannot be false to our principles." 64

Penn's work that prompted his arrest was entitled The Sandy Foundation Shaken. ${ }^{65}$ The book seemingly questioned and criticized doctrines important to traditional Christian faith such as the Trinity. Before his release, Penn wrote another work, Innocency with her Open Face, Presented by Way of Apology for the Book entitled, The Sandy Foundation Shaken" clarifying that he did not reject the deity of Christ. Therein he writes,

From whence I conclude Christ the Saviour to be God; for otherwise God would not be himself; since if Christ be distinct from God, and yet God's power and wisdom, God would be without his own power and wisdom; but inasmuch as it is impossible God's power and wisdom should be distinct or divided from himself, it reasonably follows, that Christ, who is that power and wisdom, is not distinct from God, but entirely that very same God. .. . 'God is light, and in him is no darkness at all'; from whence I assert the unity of God....66

\section{PENN'S CHARTER OF PRIVILEGES: RELIGIOUS LIBERTY IN PENNSYLVANIA.}

Admiral Penn and his Quaker son were reconciled in spite of their differences over religion. Although Admiral Penn never adopted Quaker beliefs, he admired his son's courage and conscience. His father had good reason to admire his son. 
Penn had gone to jail on various occasions for both his theology and street preaching. He then defended himself as he was a lawyer. His landmark case appealed to the right of Englishmen to have a jury trial according to the Magna Charta. The judge told the jury that the law and the facts required that Penn be found guilty. Penn told the jury that they had the right to find him innocent if they believed that the law was unjust. The jury acquitted Penn and to the judge's consternation declared that the law was not binding as it was unjust. Penn's trial not only allowed him to go free, but it established the right to trial by jury in the English speaking world.

When the Admiral died, the younger Penn became his heir, leaving a $£ 1500$ a year income from estates in England and Ireland. Charles II also owed the Admiral's estate $£ 15,000$ for a monetary loan. Since the King was facing financial difficulties, he was disposed to Penn's request to be paid by a tract of land in America north of Maryland with the Delaware on its east; its western limits the same as those of Maryland and its northern boundary as far as plantable country extended. An essential part of receiving the land was that Penn would be its proprietary governor with the power to make its form of government and its essential laws. This enabled Penn's dream of a commonwealth with religious liberty to become a reality.

Penn's petition was received June 14, 1680, and the patent was signed by the King on March 4, 1681. The name of the new territory was left blank for the King to fill in. Charles chose the name Pennsylvania. Penn said he had wanted it to be New Wales, but accepted the name and said it was named in his 
father's honor. He did not want it thought it was named for him, saying, "For I feared lest it should be looked on as a vanity in me."67

Penn became heir of his father's estate and sought payment of the royal debt to his father's estate by a land grant, which was granted to him. This became Pennsylvania. Penn's land grant received the current boundaries of Pennsylvania. He began to publicize the opportunity for settlement with religious liberty. Penn's 1682 Charter had the same language of religious liberty as in 1701. But in 1701, the final revision of Charter was approved.

Philadelphia and Pennsylvania grew faster than any settlement in the New World. They became the safe haven for all religious groups, Quakers, Mennonites, Anabaptists, Baptists, Presbyterians, Catholics, etc. For a period of time, Philadelphia was the only place in the entire English speaking world where religious liberty is available to Roman Catholics since that right had been lost in Maryland.

Penn's City of Brotherly Love was unique in its 5 emphases that would ultimately become the model for all other US states, and the Constitution of the United States:

- autonomy for the churches;

- separation of the institutional church from the state;

- freedom of conscience for the individual;

- the informal support of religion as a creator of the morality necessary for good citizenship;

- and natural law as the intellectual basis for policies in the colony and the state. ${ }^{68}$ 
William Penn's Charter of Privileges was written on October 28, 1701, seventy-five years before the Declaration of Independence. In his Charter, Penn gave to the new world the freedom to worship God according to the dictates of one's own conscience. His Charter declares,

I doe hereby Grant and Declare that noe person or persons Inhabiting in this Province or Territories who shall Confesse and Acknowledge one Almighty God the Creator upholder and Ruler of the world and professe him or themselves Obliged to live quietly under the Civill Government shall be in any case molested or prejudiced in his or theire person or Estate because of his or theire Conscientious perswasion or practice nor be compelled to frequent or mentaine any Religious Worship place or Ministry contrary to his or theire mind or doe or Suffer any other act or thing contrary to theire Religious perswasion.

So important were these provisions, Penn ensured that they could never be violated. At the end of the Charter, Penn reiterates:

But because the happiness of Mankind Descends So much upon the Enjoying of Libertie of theire Consciences as aforesaid I Doe hereby Solemnly Declare Promise and Grant for me my heires and Assignes that the first Article of this Charter Relateing to Liberty of Conscience and every part and Clause therein according to the True Intent and meaneing thereof shall be kept and remaine without any Alteration Inviolably for ever. 
Revolutionary for its time, Penn's Charter is the American Magna Charta of religious liberty. Penn's dream was that Philadelphia would be a city where brothers would truly love one another. The name "Philadelphia" was taken from the Bible in Romans 12:10 and Revelation 3:7. It literally translates from Greek as "the city of brotherly love". Penn's city was to be where liberties unknown elsewhere in the world would be legislated and practiced. Hence Penn's Charter set a new standard for religious liberty that profoundly impacted America's history, as well as Presbyterian history, and provides an example for the world today. Indeed, as reflected on a plaque at St. Joseph's Church in Philadelphia, for a period of time Penn's City was the only place in the entire Englishspeaking world where religious liberty was available to Roman Catholics. When an English priest came to Philadelphia in 1741 to assist at St. Joseph's, he wrote: “We have at present all liberty imaginable in the exercise of our business, and are not only esteemed, but revered, as I might say, by the better sort of people." ${ }^{69}$

Penn came to America twice to oversee his "holy experiment" as he called it. He carefully planned the city of Philadelphia before it was settled, remarking in a letter to Robert Turner dated March 1, 1681: “... [the grant] 'tis a clear and just thing, and my God that has given it me through many difficulties, will, I believe, bless and make it the seed of a nation. I shall have a tender care to the government, that it will be well laid at first." 70 The "seed of a nation" it did indeed become - with freedom of conscience as its first roots. The 
plight of the Quakers in England motivated them to pursue religious liberty that was afforded to them in Penn's new colony. ${ }^{71}$ What is known today as the American Liberty Bell rang out American independence in July 1776. It had been ordered in 1751 to commemorate the fiftieth anniversary of Penn's Charter and the religious liberty it established. Fittingly, the biblical Jubilee text of Leviticus 25:10 was placed upon the Bell, "Proclaim Liberty Throughout the Land Unto All the Inhabitants Thereof".

Pennsylvania's advances in religious liberty were then recognized to be ahead of other American colonies such as George Washington's Virginia. ${ }^{72}$ Jefferson wrote, "Our sister states of Pennsylvania and New York, however, have long subsisted without any establishment at all. The experiment was new and doubtful when they made it. It has answered beyond conception. They flourish infinitely. Religion is well supported; of various kinds, indeed, but all good enough; all sufficient to preserve peace and order."73 James Madison described the persecution that was occurring in his own state of Virginia:

Poverty and luxury prevail among all sorts; pride, ignorance, and knavery among the priesthood, and vice and wickedness among the laity. This is bad enough, but it is not the worst I have to tell you. That diabolical, hell-conceived principle of persecution rages among some; and to their eternal infamy, the clergy can furnish their quota of imps for such business. This vexes me the worst of anything whatever. There are at this time in the adjacent country not less than five or six well-meaning 
men in close jail for publishing their religious sentiments, which in the main are very orthodox. I have neither patience to hear, talk, or think of anything relative to this matter; for I have squabbled and scolded, abused and ridiculed, so long about it to little purpose, that I am without common patience. So I must beg you to pity me, and pray for liberty of conscience to all. ${ }^{74}$

\section{EMBRACING RELIGIOUS LIBERTY, AMERICAN PRESBYTERIANS CHANGE THE WESTMINSTER CONFESSION.}

In 1706, the first Presbytery was organized in America. By 1716 the First Presbyterian Synod was organized. Presbyterians greatly benefited from religious liberty in Pennsylvania. Consequently, emigration from Ireland and Scotland to Pennsylvania intensified. A letter from 1729 explains reasons why so many Scotch-Irish emigrated,

The Presbyterian ministers have taken their share of pains to seduce their poor ignorant hearers by bellowing from their pulpits against the landlords and the clergy, calling them rackers of rents and screwers of tithes, with other reflections of this nature which they know is pleasing to their people; at the same time telling them that God had appointed a country for them to dwell in (naming New England) and desires them to depart thence, where they will be freed form the bondage of Egypt and go to the land of Canaan etc. ${ }^{75}$ 
Nevertheless, Presbyterians continued to experience various inequities in the new world as in the Colony of Virginia, where the Anglican Church was the established religion. ${ }^{76}$

Eventually, the experience of Religious liberty in the American Colonies enabled the Presbyterian heritage to flourish. Under leaders such as John Witherspoon, the President of Princeton, and the only clergyman to sign the Declaration of Independence, the Presbyterian Church in the United States embraced thoroughgoing religious liberty and amended its Confession to express this new commitment. The American edition of the Confession, adopted in 1789, affirmed that the government should protect all faiths, not just one established religion.

So in Philadelphia, American Presbyterianism proclaimed that it no longer supported governmentally enforced religion, but instead advocated religious liberty. A comparison of the original version of the Presbyterian Westminster Confession of Faith, and the altered American text reveals striking differences. The 1647 original affirms that the magistrate has coercive power in religious matters:

The civil magistrate may not assume to himself the administration of the Word and sacraments, or the power of the keys of the kingdom of heaven; yet he hath authority, and it is his duty, to take order that unity and peace be preserved in the Church, that the truth of God be kept pure and entire, that all blasphemies and heresies be suppressed, all corruptions and 
abuses in worship and discipline prevented or reformed, and all the ordinances of God duly settled, administered, and observed. For the better effecting whereof, he hath power to call synods, to be present at them and to provide that whatsoever is transacted in them be according to the mind of God (XXIII. 3).

The American Presbyterian version, however, disagrees by affirming a commitment to religious liberty. The altered Westminster Confession of Faith asserts:

Civil magistrates may not assume to themselves the administration of the Word and sacraments; or the power of the keys of the kingdom of heaven; or, in the least, interfere in matters of faith. Yet, as nursing fathers, it is the duty of civil magistrates to protect the Church of our common Lord, without giving the preference to any denomination of Christians above the rest, in such a manner that all ecclesiastical persons whatever shall enjoy the full, free, and unquestioned liberty of discharging every part of their sacred functions, without violence or danger. And, as Jesus Christ hath appointed a regular government and discipline in his Church, no law of any commonwealth should interfere with, let, or hinder, the due exercise thereof, among the voluntary members of any denomination of Christians, according to their own profession and belief. It is the duty of civil magistrates to protect the person and good name of all their people, in such an effectual manner as that no person be suffered, either upon pretense of religion or of infidelity, to offer any indignity, violence, abuse, 
or injury to any other person whatsoever: and to take order, that all religious and ecclesiastical assemblies be held without molestation or disturbance (XXIII. 3).

James H. Smylie, editor of the Journal of Presbyterian History, explains,

Since 1729 the Westminster Confession of Faith and the Larger and Shorter Catechisms had been the confessional standards of American Presbyterianism. When the General Assembly constituted itself, the commissioners did not deliberate long on alterations. The standards were altered in those places which provided for the freedom of the denomination from the interference by the civil authority. Thus, the words "and by the power of the Civil Magistrate" were dropped from Chapter XX.4; and XXXI.2, giving the civil magistrate power to call synods, was dropped altogether. The commissioners rewrote completely Chapter XXIII.3, on the relation of the civil magistrate to the administration of the word and Sacrament and the keys of the kingdom ... Presbyterians deleted from the Larger Catechism, question 109, that "tolerating a false religion" was a sin against the Second Commandment. The significance of these changes may be seen by comparing the standards at these points to what they were in $1729 \ldots{ }^{77}$ 


\section{RELIGIOUS LIBERTY IN THE US CONSTITUTION AND THE BILL OF RIGHTS.}

The pursuit of legal protections for religious liberty advanced to Virginia, with the help of James Madison and then Governor Thomas Jefferson. In 1786, Jefferson's “An Act for Establishing Religious Freedom" became state law. Then in 1787, delegates from the newly independent states met in Philadelphia at the Constitutional Convention. While protections for religious liberty did not arise in the framing of the Constitution, there was sensitivity for religious differences. Thus the U.S. Constitution prohibits tests of religion for service in the federal government. Even the form of the swearing of the oath of office in the Constitution provides the alternative "to affirm" to protect the beliefs of Quakers, Anabaptists and other traditions which consider taking oaths to be unscriptural.

On December 15, 1791, the First Amendment was ratified. This established constitutional guarantees for religious liberty by mandating:

Congress shall make no law respecting an establishment of religion, or prohibiting the free exercise thereof; or abridging the freedom of speech, or of the press, or the right of the people peaceably to assemble, and to petition the Government for a redress of grievances. ${ }^{78}$

The drafting of the First Amendment was led by James Madison and several others. And in this process a Protestant 
minister made a significant call for religious liberty by way of an American Bill of Rights. Madison received a letter dated February 28, 1788 entitled “John Leland's Objections to the Constitution without a Bill of Rights". Reverend Leland was a Baptist minister. He wrote:

What is clearest of all Religious Liberty, is not sufficiently secured, No Religious test is Required as a qualification to fill any office under the United States, but if a Majority of Congress with the President favour one System more then another, they may oblige all others to pay to the support of their System as much as they please, and if oppression does not ensue, it will be owing to the Mildness of Administration and not to any Constitutional defence, and if the Manners of People are so far Corrupted, that they cannot live by Republican principles, it is Very Dangerous leaving Religious Liberty at their mercy.79

Twenty iterations of the language for the First Amendment ensued in the Congressional debate before the final version that we now know as the First Amendment was sent to the House on September 24, 1789. ${ }^{80}$ Not once in any of those twenty attempts to write the language of the First Amendment did the phrase "separation of Church and State" appear. The word "conscience", although not appearing in the final form, occurs in twelve of the proposed iterations. Thus, it is evident that the motivating concern of the drafters of the First Amendment was to protect conscience from government, not to protect government from religion. Within two years, the ten 
amendments known as the Bill of Rights were approved, providing the foundation for the protection of the fundamental rights and liberties enjoyed in America.

Religious liberty continued to advance in the United States. Thus various historic denominations re-wrote their creeds and forms of governments so that they would reflect the American Federal Constitutional system of the nonestablishment of religion with the free exercise of religion. The state churches of New England and other states were eventually disestablished to conform to the freedom of religion on the federal level. Many state constitutions included the language of "protecting the right of conscience".

Deep satisfaction for the establishment of American religious liberty can be seen in President George Washington's August 17, 1790 letter to the Jewish Congregation in Rhode Island. America's first President under the Constitution celebrated religious liberty when he wrote:

The Citizens of the United States of America have a right to applaud themselves for having given to Mankind examples of an enlarged and liberal policy, a policy worthy of imitation. All possess alike liberty of conscience and immunities of citizenship. It is now no more that toleration is spoken of, as if it was by the indulgence of one class of people, that another enjoyed the exercise of their inherent natural rights. For happily the Government of the Unites States, which gives to bigotry no sanction, to persecution no assistance, requires only that they who live under its protection should demean 
themselves as good citizens, in giving it on all occasions their effectual support... ${ }^{81}$

A little over twenty years after the ratification of the First Amendment, James Madison continued to celebrate the success of the American First Amendment and its provision for religious liberty. He wrote to Edward Livingston, July 10, 1822,

It was the belief of all sects at one time that the establishment of Religion by law, was right \& necessary; that the true religion ought to be established in exclusion of every other; and that the only question to be decided was which was the true religion. The example of Holland proved that a toleration of sects, dissenting from the established sect was safe \& even useful. The example of the Colonies, now States, which rejected religious establishments altogether, proved that all Sects might be safely \& advantageously put on a footing of equal \& entire freedom. ... ${ }^{82}$

\section{RELIGIOUS LIBERTY IN THE GLOBAL WORLD.}

Religious liberty as an ideal has to be worked out in specific contexts. Thus in the United States, there have been many denominations and academic institutions who have struggled with the application of religious freedom. Thus debates have arisen in regard to the discipline of a member's beliefs in light of a church's creed, or the limits of academic freedom. Efforts to define the boundaries of religious liberty have continued to arise in America as the limits of religious 
liberty have been tested in the courts. ${ }^{83}$ Instances of such legal debates have included:

- Episcopalians - the right to have an alien working as a pastor in light of immigration laws

- Mormons - the legitimacy of polygamy

- Amish - home schooling, regulations on vehicles

- Jehovah Witnesses - blood transfusions, pledge to flag

- Church property rights and taxation of religious institutions

- Prayer, scripture, Ten Commandments in schools and public places

- Pacifism and conscientious objector status

There has been a substantial interest of the United States in human rights issues beyond its own borders. The issue of world-wide religious freedom was highlighted throughout the 1980s and 1990s by a growing awareness of human rights abuses abroad. The result was a call for more articulate United States human rights policies. This call brought into focus the plight of many around the world who are struggling to preserve their freedom of conscience with respect to worship in the face of fierce opposition from those in political power.

In the 1990s, religious organizations began to lobby Congress to focus on religious persecution abroad. Ultimately, in 1998 the International Religious Freedom Act (IRFA) was passed unanimously by both Houses of Congress and was signed by President Clinton. The Act had its foundation in the "American passion for religious liberty and the conviction that 
it was the birthright of every human being." ${ }^{84}$ As a direct result of this Act, the Office of International Religious Freedom was established and in May, 1999 the first Ambassador at Large for International Religious Freedom was sworn into office.

In its first report, delivered in 2000, the Office noted, "the vast majority of the world's governments have committed themselves to respect religious freedom ... [many] affirming the right of every human being 'to have or to adopt a religion or belief of his choice.'" 85 The report also found however, that there is often a large gap between word and deed, leading to religious persecution, stigmatization of minority religions as "sects", or legal restrictions on religious practices. A strong heritage of protecting religious liberty has allowed the United States to accept, and aim to meet, the standards of the Universal Declaration on Human Rights ${ }^{86}$ and other international instruments designed to set standards by which the international community can measure its progress in the area of religious liberty. "The United States acknowledges and accepts its responsibility to meet these standards in the safeguarding and protection of religious liberty." 87 Yet there is a growing concern that the current administration has diminished the importance of religious liberty in America's international policy concerns. $^{88}$

Religious liberty has been embraced by leading religious bodies as well. Thus the Amsterdam Declaration of Religious Liberty of the World Council of Churches states that religious liberty has the following four rights: 
1. Every person has the right to determine his own faith and creed.

2. Every person has the right to express his religious beliefs in worship, teaching and practice and to proclaim the implications of his beliefs for relationships in a social or political community.

3. Every person has the right to associate with others and to organize with them for religious purposes.

4. Every religious organization formed or maintained by action in accordance with the rights of individual persons, has the right to determine its policies and practices for the accomplishments of its chosen purposes. ${ }^{89}$

The WCC Declaration also offers appropriate corresponding limitations to these four rights:

1. The liberty of conscience, or right to determine one's belief is practically subject to no legal limitation at all.

2. The liberty of religious expression is subject to such limitations, prescribed by law as are necessary to protect order and welfare, morals and the rights and freedoms of others.

3. The liberty of religious association is subject to the same limits imposed on all associations by non-discriminatory laws.

4. Similarly, the corporate religious freedom is limited by the provisions of non-discriminatory laws passed in the interest of public order and well-being. ${ }^{90}$ 
Moreover, an event with vast significance for religious liberty worldwide was the promulgation in 1965 of the document Declaration of Religious Freedom or Dignitatis Humanae by the Second Vatican Council. Its significance lies in the immense worldwide influence of the Roman Catholic tradition, not only in history, but in contemporary international affairs. Its powerful language declares that the Roman Catholic Church rejects the persecution of minority faiths, and that it is committed to universal religious liberty and the liberty of the conscience. ${ }^{91}$

\section{Dignitatis Humanae states:}

A sense of the dignity of the human person has been impressing itself more and more deeply on the consciousness of contemporary man, and the demand is increasingly made that men should act on their own judgment, enjoying and making use of a responsible freedom, not driven by coercion but motivated by a sense of duty. The demand is likewise made that constitutional limits should be set to the powers of government, in order that there may be no encroachment on the rightful freedom of the individual and of associations. This demand for freedom in human society chiefly concerns the quest for the values proper to the human spirit. It concerns, in the first place, the free exercise of religion in society. This Vatican Council takes careful note of these desires in the minds of men. It proposes to declare that they are greatly in accord with truth and justice.... 
This Vatican council declares that the human person has a right to religious freedom. This freedom means that all men are to be immune from coercion on the part of individuals or of social groups and of any human power, in such wise that in religious matters no one is to be forced to act in a manner contrary to his own conscience, whether privately or publicly, whether alone or in association with others, within due limits. The council further declares that the right to religious freedom has its foundation in the very dignity of the human person as this dignity is known through the revealed word of God and by reason itself. This right of the human person to religious freedom is to be recognized in the constitutional law whereby society is governed and thus it is to become a civil right. ${ }^{92}$

However, there are still many nations with state mandated religions. Civil governments led by exclusive religious beliefs and practices are incompatible with the principles of religious liberty. ${ }^{93}$ Religious liberty cannot be fully embraced with established theocracies. ${ }^{94}$

Thus half the world continues to face persecution marked by untold tragedy because of hostilities toward differing faith perspectives. Sadly, much of the world still does not enjoy the religious freedom that Americans and many others experience on a daily basis. ${ }^{95}$ As a case in point, a recent news magazine in the United States reported the growing worldwide murder of Christians by Muslims. ${ }^{96}$ 
There is an established connection between political freedom and religious belief, ${ }^{97}$ and between religious liberty and economic prosperity. If mercy and justice in the face of human suffering were not reasons enough, this link between religious liberty and a nation's economic prosperity should propel us to work to advance religious and civil liberty. The Index of Economic Freedom makes it clear that "prosperity is the result of freedom, and the surest way to improve the economic well-being of a nation is to ensure freedom for its citizens." ${ }^{\prime 98}$

So in conclusion, it is my hope that Indonesia will pursue the path of religious liberty in all of its fullness rather than a truncated view of religious toleration or the difficult to define concept of "religious harmony". For after all, one man's harmony may be another man's dissonance. One man's peace may be another man's persecution. The solution for this tension is freedom coupled with mutual respect. As William Penn once told the British Parliament, "We must give the liberty we ask and cannot be false to our principles though it were to relieve ourselves." 99 To say it another way, "The freedom we desire for ourselves, we must grant to others as well."

Religious liberty has traversed a long and difficult journey to become a global value. But the story of its journey from America to the world manifests that Protestant Christianity has been a vital force in recognizing this core human freedom in nations worldwide. 
${ }^{1}$ For general studies on the history of religion in America, see Sydney E. Ahlstrom, A Religious History of the American People (New Haven: Yale University Press, 1979); Edwin S. Gaustad, A Documentary History of Religion in America to the Civil War (Grand Rapids: Eerdmans, 1993); William W. Sweet, The Story of Religion in America (Grand Rapids: Baker Book House, 1973).

${ }^{2}$ Alexis de Tocqueville, Democracy in America Book I Chapter 17 quoted in Virginia.edu, accessed May 19, 2015, http://xroads.virginia.edu/ Hyper/DETOC/religion/ch1_17.htm.

${ }^{3}$ James H. Hutson, Religion and the Founding of the American Republic (Washington: Library of Congress, 1998), 1

4 The following outline may be of help to understand the development of religion in America. Religion and the Founding of the American Republic by James H. Hutson

1607 Virginia founded. Church of England planted in British North America

$1620 \quad$ Plymouth settled by Pilgrims

1629-30 Massachusetts Bay Colony founded. Congregationalism planted in British North America

1634 Maryland founded. Roman Catholic Church planted in British North America

1636 Roger Williams expelled from Massachusetts. He found Rhode Island as a haven for religious dissidents

1654 Jews, fleeing religious persecution in Brazil, arrive in New York City.

1659-62 Quakers hanged in Massachusetts, persecuted in Virginial victims of the prevailing belief in enforced religious uniformity.

1681 William Penn, leader of the Quakers, receives a charter for Pennsylvania; Penn establishes religious liberty in the colony

1683 Members of the German sects begin arriving in Pennsylvania, attracted by religious liberty.

1689 English Parliament passes the Toleration Act which improves the conditions of dissenters throughout the American colonies 
ca. 1735-45 The Great Awakening, a religious revival throughout the English-speaking world, invigorates and polarizes religious life in America.

1755 Separate Baptists, a product of the Great Awakening, begin proselytizing in the South.

1758 Presbyterian Church, split by the Great Awakening into the New Side and Old Side, reunites.

1766 First Methodist meeting (in New York City) in the American colonies

1776 American independence declared.

1780 Massachusetts Constitution adopted; state support of religion provided.

$1784 \quad$ Methodist Episcopal Church established

1786 Jefferson's Bill for Establishing Religious Freedom passed by the Virginia Assembly; state support of religion prohibited.

1787 U.S. Constitution adopted; religious tests for public service under the federal government prohibited.

1788-89 Protestant Episcopal Church established; ties with Church of England cut; Presbyterian Church also established on a new footing.

1789 Bill of Rights passed by Congress; proscribes congressional "establishment" of religion and congressional interference with the "free exercise thereof"

1800 Major revivals in Kentucky which spread east and initiate a long period of evangelical dominance in American religion.

1816 African Methodist Episcopal Church established.

1830 Joseph Smith founds Church of Jesus Christ of Latter-Day Saints (Mormons).

1832 Disciples of Christ established.

1833 Massachusetts becomes the final jurisdiction to renounce state support of religion.

1835 Tocqueville's Democracy in America published, in which the famous French commentator observed that Americans considered religion "indispensable to the maintenance of republican institutions." 
${ }^{5}$ See M. Searles Bates, Religious Liberty: An Inquiry (New York: International Missionary Council, 1945); Giovanni Miegge, Religious Liberty (New York: Association Press, 1957); Cecil Northcott, Religious Liberty (New York: Macmillan Company, 1949); James E. Wood, "Religions and Religious Liberty." Journal of Church and State Vol. 33, No. 2 (1991).

${ }^{6}$ For studies of religious liberty in America, see Denise Lardner Carmody and John Tully Carmody, The Republic of Many Nations (New York: Paragon House, 1990); Sanford H. Cobb, The Rise of Religious Liberty in America (New York: Macmillan Company, 1902); M. Stanton Evans, The Theme Is Freedom: Religion, Politics, and the American Tradition (Washington: Regnery Publishing, Inc., 1994); James H. Hutson, Religion and the Founding of the American Republic (Washington, Library of Congress, 1998); Gary E. McCuen, Religion and Politics: Issues in Religious Liberty (Hudson, Wisconsin: Gary E. McCuen Publications, 1989). For studies of religious liberty in the American revolutionary era, see Bernard Bailyn, The Ideological Origins of the American Revolution (Cambridge: Belknap, Harvard, 1992); Franklin P. Cole, They Preached Liberty: An Anthology of Timely Quotations from New England Ministers of the American Revolution on the Subject of Liberty. (Ft. Lauderdale: Coral Ridge Ministries, n. d.); J. William Frost, A Perfect Freedom Religious Liberty in Pennsylvania (University Park, PA: The Pennsylvania State University Press, 1993).

7 Franklin D. Roosevelt, "The Four Freedoms", 1941 State of the Union Address, Speech, Umd.edu, accessed May 19, 2015, http://voicesofdemocracy.umd.edu/fdr-the-four-freedoms-speech-text/.

${ }^{8}$ George W. Bush, "May 7, 2001 Speech" quoted in "Issues of Democracy - Religious Freedom as a Human Right," Electronic Journals of the U.S. Department of State Vol. 6 No. 2 (November 2001), USEmbassy.de, accessed May 19, 2015, http://usa.usembassy.de/etexts/soc/ijde1101.pdf.

${ }_{9}$ Preamble of The Universal Declaration of Human Rights, Article 18, cited from "Issues of Democracy - Religious Freedom as a Human Right" Electronic Journals of the U.S. Department of State Vol. 6 No. 2 (November 2001), USEmbassy.de, accessed May 19, 2015, http://usa.usembassy.de/etexts/soc/ijde1101.pdf.

10 Pope John Paul II, "Religious Freedom: Condition for Peace", Message for the 1988 World Day Peace, Vatican.va, accessed May 19, 2015, http://w2.vatican.va/content/john-paul-ii/en/messages/peace/documents/hf_jp- 
ii_mes_19871208_xxi-world-day-for-peace.html.

${ }^{11}$ Adrian Karatnycky, "Religious Freedom and the New Millennium" (given at the International Coalition for Religious Freedom Conference on "Religious Freedom and the New Millennium," Berlin, Germany, May 29-31, 1998), 111.

12 See Adrian Karatnycky, “The Changing Landscape of Religious Freedom", (given at the International Coalition of Religious Freedom Conference on "Religious Freedom in Latin America and the New Millennium," San Paolo, Brazil, October 10-12, 1998), http://www.icrf.com.

${ }^{13}$ Ninan Koshy, Risk Books Series: Religious Freedom in a Changing

World, (Geneva: WCC Publications, 1992), 51.

14 Philip Wogaman, Christian Perspectives on Politics, (London: SCM, 1988), 188.

${ }^{15}$ For studies of the history of religious liberty, see Roland $\mathrm{H}$.

Bainton, The Travail of Religious Liberty (Philadelphia: The Westminster Press, 1951); William R. Estep, Revolution Within the Revolution (Grand Rapids:

Eerdmans, 1990); Douglas F. Kelley, The Emergence of Liberty in the Modern World: The Influence of Calvin on Five Governments from the $16^{\text {th }}$ Through $18^{\text {th }}$ Centuries (Phillipsburg, N.J.: Presbyterian \& Reformed Publishing, 1992).

${ }_{16}$ Starting with the Bolshevik rise to power in 1917, followed by the Communist Regime under Stalin and Khrushchev, until the fall of the Berlin Wall, the Church and religion in the Soviet Union suffered an unending barrage of attacks on the structural and ideological underpinnings of the Church. Legal and propaganda attacks destroyed the infrastructure of the church and credibility and status of the clergy. The infamous Stalin purges successfully decimated the ranks of the clergy, as well as religious institutions, and houses of worship. In spite of Khrushchev's statements that the Soviet Union continued to support "full freedom of conscience and religion", the reality was far different. Perhaps truer to the communist view of liberty is the quote attributed to Vladimir Ilyich Lenin, "It is true that liberty is precious - so precious that it must be rationed." Attributed and quoted by Sidney and Beatrice Webb, Soviet Communism: A New Civilization? (1936), 1036.

${ }^{17}$ Harwood L. Childs et.al., eds., "The Effectiveness of Soviet AntiReligious Propaganda" in The Public Opinion Quarterly Fall 1967, Vol. XXXI, No. 3 (Princeton University Press, 1967), 375. 
18 Elizabeth Odio Benito, Study on the Current Dimensions of the Problems of Intolerance and Discrimination on Grounds of Religion or Belief, (United Nations, Commission on Human Rights, 1986).

${ }^{19}$ A review of a concordance of the Bible will show that terms such as free, freedom, liberty and their related concepts occur over a hundred times in the Scriptures.

${ }^{20}$ Writings of Washington, Vol. 31 (August 17): 1790.

${ }^{21}$ George W. Bush, Remarks at Independence Day Celebration in Philadelphia, Pennsylvania, Speech, (July 4, 2001), GPO.gov, accessed May 19, 2015, http://www.gpo.gov/fdsys/pkg/PPP-2001-book2/html/PPP-2001-book2doc-pg823.htm.

22 For original sources and classic historical works on the need for religious liberty, see Erik \& Crosby Bruun, Jay, eds., Our Nation's Archives (New York: Black Dog and Leventhal Publishers, 1999); Sebastian Castello, Wouter Valkhoff, trans. Advice to Desolate France. (Shepherdstown, West Virginia: Patmos Press, 1975); Jacob Duché, “The Duty of Standing Fast In Our Spiritual and Temporal Liberties, A Sermon, Preached in Christ Church July $7^{\text {th }}, 1775$ Before the First Battalion of the City and Liberties of Philadelphia" (Philadelphia: Printed and Sold by James Humphrey, Junior, 1775); Thomas Helwys, Richard Groves, ed. A Short Declaration of the Mystery of Iniquity. (Macon, Georgia: Mercer University Press, 1998); Thomas Helwys, "Objections Answered. Number 603" in The English Experience: Its Record in Early Printed Books Published in Facsimile (New York: Da Capo Press, 1973); Thomas Jefferson, Notes On the State Of Virginia in Thomas Jefferson, Writings, ed. Merrill D. Peterson (New York: Literary Classics of the United States, Inc., 1984); Thomas Jefferson, The Papers of Thomas Jefferson, ed. Julian P. Boyd (Princeton, N. J.: Princeton University Press, 1950); Journal of the Proceedings of Congress, 1774 (Philadelphia: Printer for the Library Company of Philadelphia, 1974); Roy P. Basler, ed., "Abraham Lincoln," in The Collected Works of Abraham Lincoln (New Brunswick: Rutgers University Press, 1953); John Locke, A Letter Concerning Toleration, Latin and English texts revised and edited with variants and an introduction by Mario Montuori. (The Hague: Martinus Nijhoff, 1963); John Locke, The Works of John Locke, A New Edition, Corrected In Ten Volumes (London: Printed for Thomas Tegg; W. Sharpe and Son, 1823; Reprinted by Scientia Verlag Aalen Germany, 1963); John Milton, Milton in The Cambridge Edition of the Poets 
Horace E. Scudder and William Vaughn Moody eds. (Boston: Houghton, Mifflin and Company, 1899); James Madison, in The Complete Madison: His Basic Writings, ed. Saul K. Padover (New York: Harper \& Brothers, 1953); James Madison, The Debates in the Federal Convention of 1787 Which Framed the Constitution of the United States of America, Reported by James Madison, A Delegate from the State of Virginia (Greenwood Press Publishers, Westport, Connecticut); Jedidah Morse, A Sermon Preached at Charlestown November 29, 1798 On the Anniversary Thanksgiving In Massachusetts - with an appendix designed to illustrate some parts of the discourse; exhibiting proof of the early existence, progress, and deleterious effects of French intrigue and influence in the United States, 2nd Edition (Cornhill, Boston: Samuel Hall Printing No. 53, 1799); John Owen, The Correspondence of John Owen (16161683), Peter Toon ed. (Cambridge and London: James Clarke \& Co. Ltd., 1970); William Penn, The Papers of William Penn, Richard S. Dunn \& Mary Maples Dunn eds. (Philadelphia: University of Pennsylvania Press, 1987); William Penn, The Select Works of William Penn Volumes I, II, III (New York: Kraus Reprint Co., 1971); William Penn, The Witness of William Penn, Frederick B. Tolles \& E. Gordon Alderfer eds. (The Macmillan Co., 1957); Robert Gordon Smith, ed., One Nation Under God: An Anthology for Americans (New York: Funk \& Wagnalls, 1961); George Washington, The Papers of George Washington: W. W. Abbot and Dorothy Twohig, eds. (Charlottesville: University Press of Virginia, 1988, 1996); George Washington, The Writings of George Washington, John C. Fitzpatrick, ed. (Washington: United States Government Printing Office, 1940); Roger Williams, The Bloody Tenet of Persecution in The Compete Writings of Roger Williams, Perry Miller, ed. (New York: Russell \& Russell, 1963).

${ }^{23}$ John Locke, A Letter concerning Toleration (1689) William Popple, trans., Constitution.org, accessed May 19, 2015, http://www.constitution.org/j1/tolerati.txt.

24 Ibid.

${ }^{25}$ Merrill D. Peterson, ed., "Notes On the State Of Virginia" in Thomas Jefferson, Writings (New York: Literary Classics of the United States, Inc., 1984), 286.

${ }^{26}$ Reinhold Niebuhr, "The Commitment of the Self and the Freedom of the Mind" in Religion E Freedom of Thought (New York: Doubleday \& Company, 1954), 59. 
${ }^{27}$ William R. Estep, Revolution within the Revolution The First Amendment in the Historical Context 1612-1789 (Grand Rapids, Michigan: William B. Eerdmans Publishing Company), 194-195.

28 Similarly in his letter to the members of the Baltimore Baptist Association, October 17, 1808, he writes:

...In our early struggles for liberty, religious freedom could not fail to become a primary object. All men felt the right, and a just animation to obtain it was exhibited by all. I was one only among the many who befriended its establishment, and am entitled but in common with others to a portion of that approbation which follows the fulfillment of a duty.

Excited by wrongs to reject a foreign government which directed our concerns according to its own interests, and not to ours, the principles which justified us were obvious to all understandings, they were imprinted in the breast of every human being; and Providence ever pleases to direct the issue of our contest in favor of that side where justice was. Since this happy separation, our nation has wisely avoided entangling itself in the system of European interests, has taken no side between its rival powers, attached itself to none of its ever-changing confederacies. Their peace is desirable; and you do me justice in saying that to preserve and secure this, has been the constant aim of my administration. The difficulties which involve it, however, are now at their ultimate term, and what will be their issue, time alone will disclose. But be it what it may, a recollection of our former vassalage in religion and civil government, will unite the zeal of every heart, and the energy of every hand, to preserve that independence in both which, under the favor of heaven, a disinterested devotion to the public cause first achieved, and a disinterested sacrifice of private interests will now maintain.....

29 "Examples of religious persecution have clearly not been restricted to any one era or to any one religion: the conflict over Ikhnaton's monotheism in Egypt, the suppression of the Canaanites by the Israelites, the execution of Socrates, the crucifixion of Jesus, the martyrdom of Christians by the Roman emperors, the condemnation of heretics and schismatics by the Christian church, the intolerance of Muslim invaders, the crusades of Christians against Muslims, the repeated persecutions and the 
pogroms against Jews by Christians, the persecution of Protestants by Catholics, the persecution of Catholics by Protestants, the Catholic and Protestant attacks on Anabaptists and other free churches, the persecution of 'witches' and Quakers in early Massachusetts, the persecution of Baptists in New England and Virginia, the persecution of Catholics throughout colonial America, and, in more recent decades, the repeated harassment of nonconventional faiths such as the Jehovah's Witnesses, the Worldwide Church of God, the Church of Scientology, and the Unification Church." James E. Wood Jr., "Religions and Religious Liberty", Journal of Church and State, Vol. 33, No. 2 (1991): 225.

${ }^{30}$ For a fuller treatment, see Peter A. Lillback, Proclaim Liberty: A Broken Bell Rings Freedom to the World (The Providence Forum, 2001).

31 Tertullian, "Apologeticum," Tertullian.org, accessed May 19, 2015, http://www.tertullian.org/works/apologeticum.htm.

32 Ninan Koshy, Religious Freedom in a Changing World, Risk Books Series, (Geneva: WCC Publications, 1992), 53.

${ }_{33}$ M. Searle Bates, Religious Liberty, an Enquiry (New York: International Missionary Council, 1945), 135.

${ }^{34}$ Martin Luther, Imperial Diet of Worms (1521), accessed May 19, 2015, http://www.luther.de/en/worms.html.

35 In Benson Bobrick, Wide as the Waters: The Story of the English Bible and the Revolution It Inspired (New York: Simon \& Schuster, 2001), 87.

36 John Milton, “On The Late Massacre in Piedmont” (Sonnet in 1655) in Milton by William Vaughn Moody, 77.

${ }^{37}$ John T. McNeill, "Calvinism and European Politics in Historical Perspective" in Calvinism and the Political Order, George L. Hunt, ed. (Philadelphia: The Westminster Press, 1965), 36-37. Also see John T. McNeill, “The Democratic Element in Calvin's Thought" in Church History 18, No. 3 (1949): 153-171.

38 John T. McNeill, The History and Character of Calvinism (New York: Oxford University Press, 1954); Stefan Zweig, The Right To Heresy: Castellio Against Calvin (Boston: The Beacon Press, 1951).

${ }^{39}$ John T. McNeill, "Calvinism and European Politics in Historical Perspective in Calvinism and the Political Order, George L. Hunt, ed.

(Philadelphia: The Westminster Press, 1965), 23-24.

40 Paul T. Fuhrmann, "Philip Mornay and the Huguenot Challenge to 
Absolutism" in Calvinism and the Political Order, George L. Hunt, ed.

(Philadelphia: The Westminster Press, 1965), 50.

${ }^{41}$ Philip Schaff, Creeds of Christendom, vol. I, p. 218, n. 1;

42 Stefan Zweig, The Right To Heresy: Castellio Against Calvin (Boston:

The Beacon Press, 1951), 179.

43 John T. McNeill, The History and Character of Calvinism (New York: Oxford University Press, 1954), 176.

${ }^{44}$ For a helpful discussion of Calvin's "backward" look to the Medieval and Constantinian persecution of heretics, and his "forward" look preparing the way for the pursuit of political liberty and resistance to tyranny, see Douglas F. Kelly, The Emergence of Liberty in the Modern World: The Influence Calvin on Five Governments from the 16th Through 18th Centuries (Phillipsburg, N. J.: Presbyterian \& Reformed Publishing, 1992), 26-32.

${ }^{45}$ Paul T. Fuhrmann, "Philip Mornay and the Huguenot Challenge to Absolutism" in Calvinism and the Political Order, George L. Hunt, ed. (Philadelphia: The Westminster Press, 1965), 63-64.

46 For background on the work of Moses Amyraut see the following:

Brian G. Armstrong, Calvinism and the Amyraut Heresy: Protestant Scholasticism and Humanism in Seventeenth-Century France (Madison: The University of Wisconsin Press, 1969); Francois Laplanche, Orthodoxie et Predication: L'oevre d'Amyraut et la Querelle de la Grace Universelle (Paris: Presses Universitaires de France, 1965); Samuel Mours, Le Protestantisme en France au Dix-Septieme Siecle (Paris: Librairie Protestante, 1967); L. J. Meteyer, L'Academie Protestante de Saumur (Paris: La Cause, 1933).

${ }^{47}$ For studies on the relationship of William Penn and Moses Amyraut see the following: Rene Fillet, "Relations entre La Touraine et la Pennsylvanie au XVIIe: Moyse Amyrault et William Penn" in Bulletin de la Societe d'etude Anglo-Americaines de XVIIe et XVIIIes. No. 37, Universite de Lille III, (November 1993): 121-140; P. Gourdin, "William Penn un etudiant saumurois ignore", in Bulletin de la Societe des Lettres Sciences et Arts du Saumurois, No. 127, 1978, 45-50; Sturgis Samuel Booth, The Huguenot Source of Penn's Ideal of Religious Tolerance (Philadelphia: no-publisher, 1956). William Penn told his biographer, William Sewell, author of the work, The History of the Rise, Increase and Progress of the Christian People Called Quakers, that he had lived in the home of Amyraut while studying in Saumur. Sewell writes, "He had been trained up in the University of Oxford, and was 
afterwards, by his father, sent into France, where, for some time, he lived (as himself once told me) with the famous preacher Moses Amyraut." Cited in Charles F. Jenkins, Remember William Penn, 1644-1944, Chairman (Commonwealth of Pennsylvania: William Penn Tercentenary Committee, Department of Public Instruction, Pennsylvania Historical Commission, 1944), 24.

48 See Armstrong, Calvinism and the Amyraut Heresy, 77-78.

${ }^{49}$ In Thomas Helwys, A Short Declaration of the Mystery of Iniquity (1611/1612), ed. Richard Groves (Macon Georgia: Mercer University Press, 1998), vii.

${ }^{50}$ Helwys, Mystery of Iniquity, 37.

${ }^{51}$ See Thomas Helwys, Objections Answered (New York: Da Capo Press, 1973).

52 See Joel Beeke and Randall J. Pederson, Meet the Puritans.

53 See L. John Van Til, Liberty of Conscience: The History of a Puritan Idea (Nutley, N. J.: The Craig Press, 1972).

${ }^{54}$ In Thomas Jefferson, Writings, ed. Merrill D. Peterson (New York: Literary Classics of the United States, Inc., 1984), 283.

55 Peter Toon, ed., The Correspondence of John Owen (1616-1683)

(Cambridge and London: James Clarke \& Co. Ltd., 1970), 145.

56 In Toon, The Correspondence of John Owen, 145-146.

57 Winthrop S. Hudson, The Story of the Christian Church (New York:

Harper \& Brothers), 83-84. James Madison actually believed that this diversity of religious expression in America was a good thing, and that it tended to protect religious liberty. He writes, "Where there is such a variety of sects, there cannot be a majority of any one sect to oppress and persecute the rest. ... The United States abound in such a variety of sects, that it is a strong security against religious persecution." Virginia Convention, June 12, 1788. In Padover, The Complete Madison, 347.

${ }^{58}$ Hutson, Religion and the Founding of the American Republic, 4.

59 Notes on the State of Virginia, Chapter 17, http://xroads.virginia.edu/ hyper/JEFFERSON/ch17.html.

60 See Cyclone Covey, The Gentle Radical: A Biography of Roger Williams (New York: The Macmillan Company, 1966); James E. Ernst, The Political Thought of Roger Williams (Port Washington, N. Y.: Kennidat Press, Inc., 1966); Edwin S. Gaustad, Liberty of Conscience: Roger Williams in America (Grand 
Rapids: William B. Eermans Publishing Company, 1991).

${ }^{61}$ Sanford Cobb, The Rise of Religious Liberty in America (New York: The Macmilliam Company, 1902), 427.

62 Ibid.

${ }^{63}$ See, for example, Winnifred King Rugg, Bianca A. Leonardo, eds., Anne Hutchinson: Unsung Heroine of History (Progressive Press, 1996).

${ }^{64}$ Cobb, The Rise of Religious Liberty, 441.

65 In The Select Works of William Penn - Vol. I (New York: Kraus Reprint Co., 1971), 129-156.

${ }^{66}$ William Penn and George Whitehead, The Christian Quaker, and His Divine Testimony Stated and Vindicated (Philadelphia, PA: Joseph Rakestraw, 1824), 94.

67 William Penn, "Letter to Richard Turner," May 1, 1681 cited from Trent and Wells, eds, Colonial Prose and Poetry (New York: Thomas Y. Crowell \& Co., 1901), Bartleby.com, last modified 2010, accessed May 19, 2015, http://www.bartleby.com/163/208.html.

68 J. William Frost, A Perfect Freedom, Religious Liberty in Pennsylvania (Pennsylvania: The Pennsylvania State University Press, 1993), 4.

${ }^{69}$ Robert H. Wilson, Freedom of Worship: Meeting Houses, Churches and Synagogues of Early Philadelphia (Philadelphia: Old Philadelphia Churches Historical Association, Inc., 1976), 15.

${ }^{70}$ Cited in Charles Michael Boland, Ring in the Jubilee (Connecticut: The Chatham Press, Inc, 1973), 13.

71 Their story as told by Thomas Jefferson in Notes on the State of Virginia, 283 is as follows: “The poor Quakers were flying from persecution in England. They cast their eyes on these new countries as asylums of civil and religious freedom; but they found them free only for the reigning sect. Several acts of the Virginia assembly of 1659,1662, and 1693, had made it penal in parents to refuse to have their children baptized; had prohibited the unlawful assembling of Quakers; had made it penal for any master of a vessel to bring a Quaker into the state; had ordered those already here, and such as should come thereafter, to be imprisoned till they should abjure the country; provided a milder punishment for their first and second return, but death for their third; had inhibited all persons from suffering their meetings in or near their houses, entertaining them individually, or disposing of books which supported their tenets. If no capital execution took place here, as did 
in New-England, it was not owing to the moderation of the church, or spirit of the legislature, as may be inferred from the law itself; but to historical circumstances which have not been handed down to us. The Anglicans retained full possession of the country about a century. Other opinions began then to creep in, and the great care of the government to support their own church, having begotten an equal degree of indolence in its clergy, twothirds of the people had become dissenters at the commencement of the present revolution. The laws indeed were still oppressive on them, but the spirit of the one party had subsided into moderation, and of the other had risen to a degree of determination which commanded respect."

72 George Washington wrote a private letter to Sir John Sinclair from Philadelphia on December 11, 1796 and said, "Pennsylvania is a large state, and from the policy of its founder, and of the government since; and especially from the celebrity of Philadelphia, has become the general receptacle of foreigners from all countries, and of all descriptions; many of whom soon take an active part in the politics of the State; and coming over full of prejudices against their own governments, some against all government, you will be enabled, without any comment of mine, to draw your own inference of their conduct." In The Writings of George WashingtonVol. 35, ed. John C. Fitzpatrick (Washington: United States Government Printing Office, 1940), 325-326. Washington had received an interesting letter several years earlier on June 23, 1760 from Andrew Burnaby who was writing to him from Philadelphia. Burnaby wrote, "Philadelphia is beyond my Expectation; and when I consider that it contains near 20,000 Inhabitants of Many Nations and Religions; that it Employs one Year with Another 350 vessels; that it has a well regulated Police; and is in beauty, Trade, Riches, not inferiour to many cities in Europe, I am lost in Admiration of that Great Man Mr Penn, who by his Wisdom and vast foresight, has been able to Accomplish such things." In W. W. Abbot, ed., The Papers of George Washington: Colonial Series 6 (Charlottesville: University Press of Virginia, 1988), 439.

${ }^{73}$ Notes on the State of Virginia, 286.

${ }^{74}$ Padover, The Complete Madison, 298.

75 Journal of Presbyterian History Volume 52-Number 4 (Winter 1974):

313.

${ }^{76}$ Consider "The Memorial of Hanover Presbytery" written on 
October 24, 1776:

To the honorable the General Assembly of Virginia:

The Memorial of the Presbytery of Hanover humbly represents, that your memorialists are governed by the same sentiments which have inspired the United States of America, and are determined that noting in our power and influence shall be wanting to give success to the common cause. We would also represent that dissenters from the Church of England in this country have ever desirous to conduct themselves as peaceable members of the civil government, for which reason they have hitherto submitted to several ecclesiastical burdens and restrictions that are inconsistent with equal liberty. But, now when the many and grievous oppressions of our mother country have laid this continent under the necessity of casting off the yoke of tyranny and forming of independent governments upon equitable and liberal foundations, we flatter ourselves that we shall be freed from all incumbrances which a spirit of domination, prejudice, or bigotry hath interwoven with most other political systems. This we are the more strongly encouraged to expect by the Declaration of Rights so universally applauded for the dignity, firmness, and precision with which it delineates and asserts the privileges of society and the prerogatives of human nature, and which we embrace as the magna charta of our commonwealth, that can never be violated without endangering the grand superstructure it was designed to maintain. Therefore we rely upon the declaration, as well as the justice of our honorable legislature, to secure us the free exercise of religion according to the dictates of our consciences. And we should fall short of our duty to ourselves, and the many and numerous congregations under our care, were we upon this occasion to neglect laying before you a statement of the religious grievances under which we have hitherto labored, that they may no longer be continued in our present form of government.

It is well known that in the frontier counties, which are justly supposed to contain a fifth part of the inhabitants of Virginia, the dissenters have borne the heavy burdens of purchasing glebes, building churches, and supporting the established clergy, where there are very few Episcopalians, either to assist in bearing the expense or to reap the advantage, and that throughout the other parts of the country there are also many thousands of zealous friends and defenders of our state who, besides the invidious and disadvantageous restrictions to which they have been subjected, annually 
pay large taxes to support an establishment from which their consciences and principles oblige them to dissent. All which are confessedly so many violations of their natural right, and in their consequences a restraint upon freedom of inquiry and private judgment.

In this enlightened age, and in a land where all of every denomination are united in the most strenuous efforts to be free, we hope and expect that our representatives will cheerfully concur in removing every species of religious as well as civil bondage. Certain it is that every argument for civil liberty gains additional strength when applied to liberty in the concerns of religion, and there is no argument in favor of establishing the Christian religion but what may be pleaded with equal propriety for establishing the tenets of Mohammed by those who believe the Al Koran; or, if this be not true, it is at least impossible for the magistrate to adjudge the right of preference among the various sects that profess the Christian faith without erecting a chair of infallibility which would lead us back to the Church of Rome.

We beg leave farther to represent that religious establishments are highly injurious to the temporal interests of any community. Without insisting upon the ambition and the arbitrary practices of those who are favored by government, or the intriguing, seditious spirit which is commonly excited by this as well as every other kind of oppression, such establishments greatly retard population, and consequently the progress of arts, sciences, and manufactories: witness the rapid growth and improvement of the northern provinces compared with this. No one can deny that the more early settlement and the many superior advantages of our country would have invited multitudes of artificers, mechanics, and other useful members of society to fix their habitation among us, who have either remained in their place of nativity or preferred worse civil governments and a more barren soil, where they might enjoy the rights of conscience more fully then they had a prospect of doing it in this. From which we infer that Virginia might have been the capital of America, and a match for the British arms without depending on others for the necessaries of war, had it not been prevented by the religious establishment. Neither can it be made to appear that the gospel needs any such civil aid. We rather conceive that when our blessed Savior declares his kingdom is not of this world he renounces all dependence upon state power; and as his weapons 
are spiritual, and were only designed to have influence upon the judgment and heart of man, we are persuaded that if mankind were left in quiet possession of their unalienable rights and privileges, Christianity, as in the days of the apostles, would continue to prevail and flourish in the greatest purity by its own native excellence and under the all-disposing providence of God.

We humbly represent that the only proper objects of civil government are the happiness and protection of men in the present state of existence, the security of the life, liberty, and the property of the citizens, and to restrain the vicious and encourage the virtuous by wholesome laws equally extending to every individual; but that the duty which we owe our Creator and the manner of discharging it can only be directed by reason and conviction and is nowhere cognizable but at the tribunal of the Universal Judge. Therefore we ask no ecclesiastical establishments for ourselves, neither can we approve of them when granted to others. This indeed would be giving exclusive or separate emoluments or privileges to one set of men without any special public services, to the common reproach and injury of every other denomination. And for the reasons recited we are induced earnestly to entreat that all laws now in force in the commonwealth which countenance religious domination may be speedily repealed; that all of every religious sect may be protected in full exercise of their several modes of worship, and exempted from all taxes for the support of any church whatsoever, further than what may be agreeable to their own private choice or voluntary obligation. This being done, all partial and invidious distinctions will be abolished, to the great honor and interest of the state, and every one be left to stand or fall according to merit, which can never be the case so long as one denomination is established in preference to others. That the great sovereign of the Universe may inspire you with unanimity, wisdom, and resolution, and bring you to a just determination on all the important concerns before you, is the fervent prayer of your memorialists. 77 "Presbyterians and the American Revolution: A Documentary Account" in Journal of Presbyterian History Volume 52 - Number 4 (Winter 1974): 473-474.

78 "First Amendment" in Transcription of the 1789 Joint Resolution of Congress Proposing 12 Amendments to the US Constitution, Bill of Rights, accessed May 19, 2015, 
http://www.archives.gov/exhibits/charters/bill_of_rights_transcript.html

${ }^{79}$ Estep, Revolution within the Revolution, 201.

80 See John Witte Jr., Religion and the American Constitutional

Experiment (Boulder, Colorado: Westview Press, 2000), 64-72. The twenty iterations leading to the First Amendment:

1. Congress shall make no laws touching religion, or to infringe the rights of conscience. $(6 / 21 / 1788)$

2. That religion, or the duty which we owe to our creator, and the manner of discharging it, can be directed only by reason and conviction, not by force or violence, and therefore all men have an equal, natural and unalienable right to the free exercise of religion according to the dictates of conscience, and that no particularly religious sect or society ought to be favored or established by law in preference to others. $(6 / 26 / 1788)$

3. That the people have an equal, natural, and unalienable right freely and peaceably to exercise their religion, according to the dictates of conscience; and that no religious sect or society ought to be favored or established by law in preference to others. (7/26/1788)

4. That any person religiously scrupulous of bearing arms ought to be exempted, upon payment of an equivalent to employ another to bear arms in his stead. (8/1/1788) (this clause added to the above)

5. The civil rights of none shall be abridged on account of religious belief or worship, nor shall any national religion be established, nor shall the full and equal rights of conscience be in any manner, or any pretext infringed. (6/8/1789 - as part of James Madison's initial draft for a Bill of Rights)

6. No state shall violate the equal right of conscience, or the freedom of the press, or the trial by jury in criminal cases. (6/8/1789 - as part of James Madison's initial draft for a Bill of Rights)

The following three clauses were presented in an initial draft of the Bill of Rights, drafted by a committee of eleven representatives duly appointed by the House following Madison's urging:

7. No religion shall be established by law, nor shall the equal rights of conscience be infringed (7/28/1789)

8. No person religiously scrupulous shall be compelled to bear arms

9. No State shall infringe the equal rights of conscience, nor the freedom of speech or of the press, nor of the right of trial by jury in criminal 
cases.

Additional iterations:

10. Congress shall make no laws touching religion or infringing the rights of conscience.

11. The equal rights of conscience, the freedom of speech or of the press, and the right of trial by jury in criminal cases, shall not be infringed by any State.

12. Congress shall make no law establishing religion, or to prevent the free exercise thereof, or to infringe the rights of conscience.

13. No person religiously scrupulous shall be compelled to bear arms in person.

14. Congress shall make no law establishing religion, or prohibiting the free exercise thereof, nor shall the rights of conscience be infringed.

15. Congress shall make no law establishing One Religious sect or Society in preference to others, nor shall the rights of conscience be infringed.

16. Congress shall not make any law, infringing the rights of conscience, or establishing any Religious Sect or Society.

17. Congress shall make no law establishing any particular denomination of religion in preference to another, or prohibiting the free exercise thereof, nor shall the rights of conscience be infringed.

18. Congress shall make no law establishing religion, or prohibiting the free exercise thereof.

19. Congress shall make no law establishing articles of faith or a mode of worship, or prohibiting the free exercise of religion, or abridging the freedom of speech, or the press, or the right of the people peaceably to assemble, and petition to the Government for the redress of grievances. $(9 / 9 / 1789)$

20. Congress shall make no Law respecting an establishment of Religion, or prohibiting the free exercise thereof. (9/24/1789).

81 Writings of Washington, Vol. 31, (August 17, 1790).

82 Padover, The Complete Madison, 309.

${ }^{83}$ For studies on religious liberty and US Supreme Court decisions, see Lynn R. Buzzard, Samuel Erickson, The Battle for Religious Liberty (Weston, Ontario: David C. Cook Publishing, 1982); Ronald B. Flowers, That Godless Court? (Louisville, Kentucky: Westminster John Knox Press, 1994); 
Stephen V. Monsma, Positive Neutrality: Letting Religious Freedom Ring (Westport, Connecticut: Greenwood Press, 1993); Krishna Prasad De, Religious Freedom Under the Indian Constitution (Calcutta: South Asia Books, 1976); John Witte, Jr., Religion and the American Constitutional Experiment Essential Rights and Liberties (Boulder, Colorado: Westview Press, 2000).

${ }^{84}$ See "Introduction," 2000 Annual Report on International Religious

Freedom (Department of State, September 5, 2000).

85 See "Executive Summary," 2000 Annual Report on International Religious Freedom (Department of State, September 5, 2000).

86 See above for the United Nations' Universal Declaration of Human Rights.

${ }^{87}$ Executive Summary. See also Paul Marshall, Their Blood Cries Out (Dallas: Word Publishing, 1997).

${ }^{88}$ Doug Bandow, "Promoting Religious Liberty: Whither the Obama Administration?" Huff Post-Religion, last modified May 25, 2011, http://www.huffingtonpost.com/doug-bandow/promoting-religiousliber_b_641534.html.

89 The World Council of Churches, Declaration on Religious Liberty, Adopted at the First Assembly of the World Council of Churches (Amsterdam, August 1948), accessed May 19, 2015, http://www.religlaw.org/content/religlaw/documents/wccdecreliglib1948.ht m.

90 Ibid.

91 The development in Roman Catholic thinking on the issue of religious liberty in the century from Pope Leo XIII to Pope Paul II is both remarkable and encouraging. Pope Leo XIII declared in 1888, "Justice therefore forbids, and reason itself forbids, the state to be godless; or to adopt a line of action which would end in godlessness - namely, to treat the various religions (as they call them) alike, and to bestow upon them promiscuously equal rights and privileges. Since, then, the profession of one religion is necessary in the state, that religion must be professed which alone is true." But Pope John Paul II proclaimed a century later in 1988, "Religious freedom, an essential element of the dignity of every person, is a cornerstone of the structure of human rights, and for this reason an irreplaceable factor in the good of individuals and of the whole of society, as well as the personal fulfillment of each individual. It follows that the freedom of individuals and 
of communities to profess and practice their religion is an essential element for peaceful human existence."

92 "Vatican II Council, "Declaration of Religious Freedom on the Right of the Individual and of Communities to Social and Civic Freedom in Religious Matters" in Religious Liberty by A. F. Carrillo De Albornoz, trans. John Drury (New York: Sheed and Ward, 1967), 169-171. See also, The Pope Speaks Magazine (Washington, D.C.), Vol. XI, 84-94. Carrillo De Albornoz's work Religious Liberty also includes the various statements on religious liberty made by the World Council of Churches. For Protestant and Catholic dialog concerning religious liberty, see Walter J. Burghardt, Religious Freedom: 1965 and 1975, A Symposium on a Historic Document (New York: Paulist Press, 1977); A. F. Carrillo De Albornoz, Religious Liberty (New York: Sheed and Ward, 1967); A. F. Carrillo De Albornoz, Roman Catholicism and Religious Liberty (Geneva: The World Council of Churches, 1959); Hans Kung, Freedom Today, Cecily Hastings, trans. (New York: Sheed \& Ward); Hans Kung and Jurgen Moltmann, The Right to Dissent (Edinburgh: T. \& T. Clark LTD, 1982); Keith J. Pavlischek, John Courtney Murray and the Dilemma of Religious Toleration (Kirksville, Missouri: Thomas Jefferson University Press, 1994); "Religious Freedom in Concilium," Theology in the Age of Renewal, Vol. 18 (New York: Paulist Press).

${ }_{93}$ Ninan Koshy writes in Risk Books Series: Religious Freedom in a Changing World (Geneva: WCC Publications, 1992), 15, "To the question of whether article 306 of the penal code of Mauritania, which deals with apostasy, conforms with UN resolutions concerning intolerance and discrimination based on religion or belief, the government replied that freedom of belief is guaranteed and protected in Mauritania: 'A person can embrace whatever beliefs he desires and no one can compel him to abandon or change those beliefs or prevent him from manifesting a faith.' Article 306, it was explained, does not apply to persons who have not embraced the Islamic faith. The reply added: 'Apostasy from the Islamic religion, which guarantees so many freedoms and so much security, stability and social justice, is regarded as high treason and everyone is aware of the penalties that states impose for this type of offence, which threatens their stability and their very existence. ... The precepts of this religion cannot be changed, since the holy law on which it is based comprises moral principles in which our society believes and any person who violates them arouses social 
indignation. Consequently apostasy constitutes one of the most serious offences against the public order and morality established by this religion.'” Reinhold Niebuhr underscores the difficulties inherent in bringing different religious communities together in a common political government when he writes, "It must be conceded that the religious commitments in a community cannot be too sharply contradictory. In India, the contrast between the Hindu and Moslem faith has made a unified national community impossible. In our own country the wide divergences between the three forms of faith rooted in a common scripture, were fortunately not so great as to furnish contrasting testimony on the nature of our common life. We have, therefore, been able to build a common life in spite of great diversity in our religious commitments and ethnic loyalties; and the community has been richer because of its multifarious components. It may be more important that the religious life has been the purer, because the pretensions of each group have been moderated by the inevitable challenge which they met in this uncoerced togetherness. In short the 'mind' of each religious group was freed by the necessity of coming to terms with other groups whose virtues may have proved that virtue is not the monopoly of any of the other groups, as was presupposed in their too self-righteous presuppositions, and whose particular approaches to problems of community tended to correct deficiencies and weaknesses in the approach of other groups." Reinhold Niebuhr, "The Commitment of the Self and the Freedom of the Mind" in Religion \& Freedom of Thought (New York: Doubleday \& Company, 1954), 58. ${ }^{94}$ For religious liberty around the world, see Elizabeth Odio Benito, Study on the Current Dimensions of the Problems of Intolerance and Discrimination on Grounds of Religion or Belief (New York: United Nations, Commission on Human Rights, 1986); Harwood L. Childs, ed. "The Effectiveness of Soviet Anti-Religious Propaganda" in The Public Opinion Quarterly Fall 1967, Vol. XXXI, No. 3 (Princeton University Press, 1967); Declaration on Religious Liberty, Assembly of the World Council of Churches (Amsterdam, 1948); Karatnycky, "Religious Freedom and the New Millennium"; Karatnycky, "The Changing Landscape of Religious Freedom; Walter Kolarz, Religion in the Soviet Union (London: Macmillan and Co., 1962); Koshy, Risk Books Series: Religious Freedom in a Changing World; Paul Marshall, Their Blood Cries Out (Dallas: Word Publishing, 1997); David E. Powell, Anti-Religious Propaganda in the Soviet Union: A Study of Mass 
Persuasion (Cambridge Massachusetts: MIT Press, 1975); The Universal Declaration of Human Rights, adopted by the United Nations on December 10, 1948.

${ }^{95}$ In a speech by President George W. Bush given May 7, 2001 to the American Jewish Committee entitled, "The First Freedom of the Soul," President Bush underscored the profound need for religious liberty worldwide:

The Middle East is the birthplace of three great religions: Judaism, Christianity, and Islam. Lasting peace in the region must respect the rights of believers in all these faiths. That's common sense. But it is also something more: it is moral sense, based upon the deep American commitment to freedom of religion.

That commitment was expressed early and eloquently by our first President, George Washington, in his famous letter to the Touro Synagogue in Newport, Rhode Island. He argued for an attitude beyond mere tolerance-a respect for the inherent and equal right of everyone to worship God as they think best. "The government of the United Sates," he said, "which gives to bigotry no sanction, to persecution no assistance, requires only that they who live under its protection, should demeans themselves as good citizens. ...

Leo Napoleon Levi, a Galveston, Texas lawyer and a president of the national B'nai Brith, drafted President Theodore Roosevelt a telegram denouncing a Russian pogrom in 1903. The Czar of Russia was so stung by Roosevelt's message that he formally refused to accept it. Some Americans complained that Roosevelt had gone too far. He replied that there were crimes so monstrous that the American conscience had to assert itself.

And there still are. Such crimes are being committed today by the government of Sudan, which is waging war against that country's traditionalist and Christian peoples. Some 2 million Sudanese have lost their lives; 4 million more have lost their homes. Hospitals, schools, churches and international relief stations have often been bombed by government warplanes over the 18 years of Sudan's civil war. The government claims to have halted air attacks. But they continue. Women and children have been abducted and sold into slavery. 
UNICEF estimates that some 12,000 to 15,000 people are now held in bondage in Sudan.

The story of the Exodus still speaks across the millennium; no society in all of history can be justly built on the backs of slaves. Sudan is a disaster area for human rights. The right of conscience has been singled out for special abuse by the Sudanese authorities. Aid agencies report that food assistance is sometimes distributed only to those willing to undergo conversion to Islam. . . .

I'm pleased to say that many countries in the region show considerable and improving respect for religious liberty: Morocco, Tunisia, Jordan and Bahrain among them. But there are other regimes, not only in North Africa and the Middle East, whose disrespect for freedom of worship is seriously disturbing.

Iraq murders dissident religious figures. Iran systematically maltreats Jews, Christians and adherents of the Baha'I faith. The Burmese junta tortures adherents of Islam, Buddhism and Christianity. Cuba monitors and harasses independent priests and ministers. Afghanistan's Taliban government has horrified the world with its disdain for fundamental human freedoms, epitomized by its destruction of ancient Buddhist works of art. And the newly independent republics of Central Asia impose troubling limits on religious expression and missionary work.

We view with special concern the intensifying attacks on religious freedom in China. In many respects, China has made great strides toward freedom in recent decades....But the Chinese government continues to display an unreasonable and unworthy suspicion of freedom of conscience. The Chinese government restricts independent religious expression. We hear alarming reports of the detention of worshippers and religious leaders. Churches, mosques have been vandalized or demolished. Traditional religious practices in Tibet have long been the target of especially harsh and unjust persecution. And most recently, adherents of the Falun Gong spiritual movement have been singled out for arrest and abuse. 
No one is a better witness to the transience of tyranny than the children of Abraham. Fourty centuries ago, the Jewish people were entrusted with a truth more enduring than any power of man. In the words of the prophet Isaiah, "This shall be My covenant with them, said the Lord; My spirit which is upon you, and the words which I have placed in your mouth, shall not be absent from your mouth, nor from the mouth of your children, nor from the mouth of your children's children - said the Lord-from now, for all time...

It is not an accident that freedom of religion is one of the central freedoms in our Bill of Rights. It is the first freedom of the human soul: the right to speak the words that God places in our mouths. We must stand for that freedom in our country. We must speak for that freedom in the world."

${ }^{96}$ Lee Habeeb, “Islamist War on Christians,” NationalReview.com, last modified September 25, 2013, http://www.nationalreview.com/article/359405/islamist-war-christians-leehabeeb.

${ }^{97}$ According to Adrian Karatnycky of Freedom House, "The correlation between Christianity and freedom at the end of the twentieth century is very strong...Christian countries, at this stage of human development, are about six times more likely to be free and democratic, as they are to be non-democratic and suffer from serious abridgements in human rights." (Adrian Karatnycky, "Religious Freedom and the New Millennium" given at the International Coalition for Religious Freedom Conference on "Religious Freedom and the New Millennium" in Berlin Germany, May 29-31, 1998, 111).

Further, "Of the 81 countries that we rate as free in our survey, 74 are majority Christian. Of the seven free countries that are not majority Christian, one is Israel, which is part of the Judeo-Christian civilization. Two others, Mauritius and South Korea, have very large Christian communities, and in some cases growing Christian communities, more that a third of their population. Of the four free countries that don't have strong relations to the Judeo-Christian tradition, one is Mali, which is predominately Muslim. Another is Taiwan, where nearly half the population is Buddhist. Another is Mongolia, which is traditional Buddhist. And finally there is Japan, which 
observes both the Buddhist and Shinto traditions." (Adrian Karatnycky, "The Changing Landscape of Religious Freedom", given at the International Coalition of Religious Freedom Conference on "Religious Freedom in Latin America and the New Millennium" October 10-12, 1998 in San Paolo, Brazil.) www.icrf.com. There is also a historic commitment of religious toleration in Buddhism. Ninan Koshy writes in Religious Freedom in a Changing World, Risk Books Series (Geneva: WCC Publications, 1992), 51 writes, “Twentythree centuries ago King Ashoka, patron of Buddhism, recommended to his subjects that they should act in accordance with a principle of toleration. 'Acting thus, we contribute to our creed by serving other. Acting otherwise, we harm our own faith, bringing discredit upon the others. He who exalts his own belief, discrediting all others does so surely to obey his religion with the intention of making a display of it. But behaving thus, he gives it the hardest blows. And for this reason concord is good only in so far as all listen to each other's creeds and live to listen to them."'

${ }^{98}$ See The Heritage Foundation home page, www.index.heritage.org.

${ }_{99}$ Edwin Chapin Sweetser and Charles Elliott St. John, Penn and Religious Liberty (Philadelphia, PA: Ketterlinus, 1908), 15. 